\title{
HUKUM ADAT vis à vis HUKUM ISLAM DI ACEH: TINJAUAN SEJARAH HUKUM DI KESULTANAN ACEH TAHUN 1516-1688 M.
}

\author{
Ayang Utriza NWAY ${ }^{1}$
}

\begin{abstract}
Abstrak
The author does figures and analyze about criminal conduct and the punishment pattern in Aceh region during 16th and 17th centuries that be done by historical approach. The substance is explores regarding punishment was applied by Aceh Sultans that be developed by ultimate sources from both local and foreign visitor testimony who come from Europe and Asia to Aceh regions. By those sources then the author is confidence to doing clear description regarding punishment system was applied during those centuries is adat law or Islamic law ones by adequate historical facts and not only blind claim. The author proposes thesis that Aceh kingdom (kesultanan) that claimed as Islamic government system but using adat law to govern and regulate their people and was not Islamic law as recent common perceptions continuing.
\end{abstract}

Kata kunci: hukum adat, hukum Islam, sejarah hukum, Kesultanan Aceh

\section{Pendahuluan}

Tuntutan penerapan syariat Islam di Indonesia menguat ketika rejim Orde Baru jatuh di tahun 1998. Daerah-daerah yang mempunyai pengalaman sejarah di bawah pemerintahan Islam (kesultanan) dahulu kala, antara lain Aceh, kembali ke romantisme masa lalu: menuntut penerapan hukum Islam. Mereka beranggapan bahwa kesultanan yang pernah memerintah daerah mereka adalah pemerintahan Islam ideal yang melaksanakan syariat Islam. Kendati seringkali mereka tidak memaparkan fakta sejarah yang sebenarnya, tetapi lebih kepada rasa keislamannya dan kedaerahannya, tuntunan penerapan hukum Islam di daerah tidak dapat dihindari lagi, bahkan semakin kuat. Di sisi lain, UU Otonomi Daerah No. 25 tahun 1999 (berlaku tahun 2000) memberi celah bagi daerah untuk menerapkan hukum Islam.

${ }^{1}$ Penulis adalah Dosen Fakultas Syariah dan Hukum UIN Syarif Hidayatullah Jakarta dan Mahasiswa Ph.D., Ecole des Hautes Etudes en Sciences Sociales (EHESS) Paris. 
Kini, penerapan syariat Islam di Aceh telah mendapatkan payung hukum melalui UU No. 44 tahun 1999 dan UU 18 tahun 2001 mengenai otonomi khusus dan penerapan syariat Islam di Aceh. Untuk tingkat praksis, Pemerintah Daerah (Pemda) Nangroe Aceh Darusssalam (NAD) telah mengeluarkan beberapa Peraturan Daerah (Perda) dalam bentuk Qanun (undang-undang): pelarangan minum minuman keras (khamar) diatur dalam Qanun No. 12/2003, mengenai berjudi (maisir) dalam Qanun No. 13/2003, dan zina (khalwat) dalam Qanun No. 14/2003. Yang menarik bagi saya di sini adalah melacak kebenaran sejarah yang selalu diklaim dan dijadikan alasan oleh sebagian kalangan Islam yang pro-penerapan syariah bahwa hukum Islam telah diterapkan sejak dulu. Tulisan ini akan melihat satu sisi aspek hukum, yaitu hukum pidana, yang digunakan oleh kesultanan Aceh untuk menjaga ketertiban dan keamanan di Aceh pada abad ke-16 dan ke-17. Benarkah hukum pidana Islam (jinâyah) yang digunakan atau justeru hukum adat yang berlaku? Dengan demikian, kita akan lebih memahami jenis hukum apa yang digunakan oleh kesultanan ini.

\section{Sekelumit Sejarah Kesultanan Aceh}

Sejarah kuno Aceh terlacak hingga ke paruh pertama abad ke-13 M. Menurut Kronika Kerajaan Aceh» bahwa kerajaan Aceh Darussalam didirikan pada Jumat, hari pertama bulan Ramadhan tahun 601 H. (1205 M.) oleh Johan Syah yang datang dari negeri Atas Angin (Timur Tengah). Ia telah mengislamkan masyarakat Aceh dan menikahi perempuan setempat. Kemudian, ia tinggal di daerah Kandjong (Tanjung Batu) ${ }^{2}$. Sumber lokal yang lain Adat Aceh, dalam bagian Silsilat Aceh atau Silsilah Raja-raja di Bandar Aceh, menyebutkan bahwa Johan Syah menjadi sultan pertama (601631 H./1204-1233 M). Ia tinggal di Kandang Aceh. Setelah dia, ada sembilan sultan berturut-turut memerintah Aceh, yaitu: Sultan Ahmad (631-665 H./1233-1266 M.), Mahmud Shah (665-708 H./1266-1308M.), Firman Shah (708-755 H./1308-1354 M.), Mansur Shah (755-811 H./1354-1408 M.), Alauddin Johan Shah (811-870 H./1408-1465 M.), Husain Shah (870-901 H./1465-1495 M.), Ali Riayat Shah (901-917/1495-1511), Shalahuddin (917946/1511-1539) dan Alauddin (946-975 H./1539-1567 M.) ${ }^{3}$.

${ }^{2}$ Ed. Dulaurier, "Chronique du royaume d'Atcheh", Journal Asiatique 3, no. VIII (1839): hal. 47-81, versi Jawi hal. 49 dan versi Prancis hal. 59.

${ }^{3}$ Dulaurier, Op. Cit., hal. 67. Thomas Braddel, "Silsilah Aceh from the Annals of Acheen," The Journal of the Indian Archipelago and Eastern Asia IV (1850): hal. 598-606, hal. 598-606. Untuk penanggalan, saya mengikuti penanggalan yang dilakukan oleh Arun 
Kronika tersebut harus ditanggapi dengan hati-hati dan cermat, sebab menurut Hoesein Djajadiningrat ${ }^{4}$, sebelum tahun 1500 Aceh adalah daerah yang kurang dikenal dan sejarah kesultanan kurang begitu jelas ${ }^{5}$. Menurutnya, hingga sultan yang ke-8 tidak ada bukti yang dapat membenarkan kronik tersebut. Namun, mulai dari sultan ke-9, kronik tersebut dapat diverifikasi dengan membandingkannya dengan sumbersumber Portugis. Djajadiningrat menyimpulkan, setelah menguji sumbersumber lokal dan Portugis, bahwa Shalahuddin (sultan ke-8) adalah Raja Ibrahim sebagaimana sumber-sumber Portugis menyebutnya. Sementara di dalam sumber lokal Bustanu' s-Salatin, Raja Ibrahim adalah Ali Mughayat Syah, sultan pertama Aceh. Namun, menurut Teuku Iskandar, Raja Ibrahim bukanlah Ali Mughayat Syah, tetapi saudara lelaki Ali Mughayat Syah ${ }^{6}$.

Menurut sumber lokal yang lain, yaitu Hikayat Aceh ${ }^{7}$, ditulis tahun 1630, bahwa pada abad ke-15 M. ada dua pusat kekuasaan di Aceh: satu di Lambri dan satu lagi di Dar al-Kamal. Raja Inayat Syah, nenek moyang Iskandar Muda dari pihak ibu, sultan terbesar Aceh saat itu tinggal di Dar alKamal. Sementara Raja Munawwar Syah ${ }^{8}$, nenek moyang Iskandar Muda dari pihak ayah, pindah dari Lambri ke Makota Alam dan tinggal di dalamnya.

Kumar Das Gupta, lihat "Acheh in Indonesian Trade and Politics 1600-1641," Disertasi Doktor, Tidak Diterbitkan, Cornell University, 1962, lihat bagian Lampiran I, hal. 203. Alfian, T. Ibrahim. Mata Uang Emas Kerajaan-Kerajaan di Aceh. Aceh: Museum Aceh, 1979.

${ }^{4}$ Hoesein Djajadiningrat, "Kesultanan Aceh (Suatu Pembahasan Atas Bahan-bahan Yang Tertera Dalam Karya Melayu Tentang Sejarah Kesultanan Aceh)", terj. Teuku Hamid, Aceh: Proyek Rehabilitasi dan Perluasan Museum, 1979, hal. 15, 19-20.

${ }^{5}$ Snouck Hurgronje telah menjelaskan juga bahwa sejarah Aceh sebelum abad ke-16 tidak diketahui, lihat Antoine Cabaton, "Une histoire critique du sultanat d'Acheh écrite par un javanais."Revue du Monde Musulman", Paris, tanpa tahun dan edisi, hal. 66-85, hal. 74.

${ }^{6}$ Teuku Iskandar (éd.), "De Hikajat Atjéh", Gravenhage: NV. De Nederlandsche Boek, 1959, hal. 35 .

${ }^{7}$ Iskandar, Op. Cit., hal. 72-75. Nenek moyang Iskandar Muda, setelah dibenarkan oleh Hoesein Djajadiningrat dan Moquette, 1. Pihak Ayah: Munawwar Syah, Shamsu Shah, Ali Mughayat Syah, Alauddin Riayat Syah, Abangta Abdul Jalil dan Sultan Mansur (Ayah Iskandar Muda). 2. Pihak Ibu: Inayat Syah, Muzaffar Syah, Firman Syah, Alauddin Riayat Syah, Puteri Raja Indera Bangsa (Ibu Iskandar Muda). Lihat Iskandar, Op. Cit., hal. 30, teks hal. 72 .

${ }^{8}$ Menurut Teuku Iskandar, nama di dalam teks adalah Raja Muzaffar Syah. Tetapi, sebenarnya, nama ini salah. Nama yang benar adalah Raja Munawwar Syah. Lihat Iskandar, Op. Cit., hal. 31 passim. 
Dua pusat kekuasaan ini hanya dipisahkan oleh sungai Aceh. Raja Munawwar Syah bermaksud menaklukkan kerajaan Raja Inayat Syah. Ia pun menyerangnya. Akibat perang ini, banyak penduduk di di Dar al-Kamal yang tewas. Kendati demikian, kesultanan Dar Kamal tidak menyerah begitu saja. Melihat kondisi seperti ini, Raja Munawwar Syah mempunyai taktik, yaitu menawarkan putranya menikah dengan putri raja Raja Inayat Syah, Setia Indera. Saat menyerahkan mahar dan kado pernikahan, Dar al-Kamal diserang secara tiba-tiba, dan karena serangan mendadak ini, Raja Inayat Syah menyatakan kalah dan takluk kepada Raja Munawwar Syah. Dengan menggabungkan dua kerajaan ini, Makota Alam dan Darul al-Kamal, Raja Munawwar Syah mendirikan kerajaan Aceh Darussalam. Setelah wafat, ia digantikan oleh putranya Syamsu Syah. Namun, Syamsu Syah meninggalkan singgasana dan menyerahkan kerajaan kepada anaknya, Ali Mughayat Syah untuk menggantikan kakeknya.

Dengan melihat berbagai informasi ini, terlepas dari ketidakpastian sejarah Aceh, nampak bahwa Ali Mughayat Syah adalah sultan terpenting di kerajaan Aceh, dan sangat mungkin untuk memverifikasi orang tersebut di dalam sumber-sumber Portugis dan lokal. Dengan demikian, sejarah kesultanan Aceh yang sesungguhnya dimulai dari masa Ali Mughayat Syah. Hal ini diperkuat oleh sumber lokal yang lain: Bustan al-Salatin, ditulis pada 1047 H./1638 M. menjelaskan bahwa yang mendirikan kerajaan Aceh Darussalam adalah Sultan Ali Mughayat Syah pada tahun 913 H./1507 M9 berdasarkan bukti-bukti ini, TH. W. Juynboll dan P. Voorhoeve menyimpulkan bahwa sultan Ali Mughayat Syah (ca.1516-1530) adalah pendiri yang sesungguhnya kesultanan $\mathrm{Aceh}^{10}$. Ia mengembangkan dan meluaskan wilayah kesultanan Aceh. Mughayat Syah menaklukkan Daya di Barat pada tahun 1520, dan Pedir dan Pasai di Timur pada tahun 1524".

Aceh, yang terletak di ujung pulau Sumatra, pada abad ke-16 dan ke17 pedalamannya ditutupi oleh hutan dan pegunungan. Daerah Aceh sangat subur untuk pertanian dan perkebunan dan diairi oleh sungai-sungai yang

9 Nuruddin ar-Raniri, "Bustanu' s-Salatin, Bab II, Fasal 13", disunting oleh T. Iskandar, Kuala Lumpur: Dewan Bahasa dan Pustaka, 1966, hal. 31. Bustan menyatakan bahwa Sultan menaklukkan Pidir dan Samudera. Ali Mughayat Syah wafat pada 7 Agustus 1530 menurut tulisan di batu nisannya, lihat catatan Iskandar dalam ar-Raniri, Op. Cit., hal. 75.

${ }^{10}$ Saya mengikuti daftar kesultanan Aceh yang dibuat oleh Djajadiningrat dan diperbarui oleh Juynboll dan Voorhoeve, lihat Th. W. Juynboll dan P. Voorhoeve, "Atjèh," di dalam "Encyclopédie de l'Islam", hal. 761-766. Leiden dan Paris: E.J. Brill dan G.P.Maisonneuve \& Larose S.A., 1991.

${ }^{11}$ Djajadiningrat, Op. Cit., hal. 21. 
mengalir. Sungai-sungai inilah yang menghubungkan daerah-daerah di Aceh ke laut lepas di mana mereka memanfaatkannya untuk berdagang. Sungaisungai ini digunakan hanya untuk kapal-kapal kecil untuk mengangkut hasil pertanian ke Kutaradja (Kota Raja) ${ }^{12}$.

Aceh menjadi kerajaan terbesar di Sumatra sepanjang abad ke-16 dan ke-17. Dalam ranah politik, kesultanan Aceh mengontrol hampir sebagian besar pantai di pulau Sumatera. Bagian Timur kesultanan Aceh hingga mencapai Deli. Sementara bagian Barat membentang hingga Daya dan Padang, bahkan Indrapura. Pusat kesultanan meliputi tiga kota penting, yaitu: Pedir, Pasai, dan Samarlangga hingga meluas ke daerah Jambi. Kesultanan ini juga menguasai sebagian besar Semenanjung Melayu, yang terletak tepat berhadapan dengan pulau Sumatera, yaitu: Kedah, Perak hingga Johor dan Pahang. Dalam bidang ekonomi, pelabuhan Aceh menarik banyak pedagang yang berdatangan dari berbagai negara, antara lain: Prancis, Inggeris, Belanda, China, Burma, Thailand, Taiwan, Persia, Turki, India, dan lain-lain untuk berdagang.

\section{Hukum Pidana di Kesultanan Aceh}

Dengan kondisi Aceh yang demikian maju pada saat itu, maka sangat menarik untuk mengetahui jenis hukuman yang digunakan oleh kesultanan ini dalam menjaga keteraturan masyarakatnya. Hukuman apa kiranya yang digunakan oleh kesultanan Aceh untuk menghukum para pelaku tindak kriminal di Aceh: hukum adat atau hukum Islam? Penelusuran sejarah seperti tertuang di bawah ini akan memberikan jawaban atas pertanyaan itu.

\section{A. Perzinaan}

Hukuman perzinaan pertama kali yang diketahui di Kesultanan Aceh adalah pada masa sultan pertama, yaitu Ali Mughayat Syah (ca. 1516-1530). Kejadian ini bukan di Aceh, tetapi di Tiku berdasarkan kesaksian dua pelancong Prancis: Jean dan Raoul Parmentier de Dieppe. Mereka tiba di Tiku, dekat Padang, pada 2 Oktober 1529. Tiku sendiri pada saat itu belum termasuk bagian dari wilayah Kesultanan Aceh kecuali setelah tahun 1560.

${ }^{12}$ Sekarang nama kota tersebut diganti dengan nama Banda Aceh. 
Jean dan Raoul mengatakan bahwa orang-orang Tiku pada saat itu telah beragama Islam. Mengenai hukuman pidana yang dipraktekkan oleh masyarakat Tiku, Jean dan Raoul menulis ${ }^{13}$ :

L'adultère est puni de la peine de mort pour les hommes et d'esclavage pour les femmes, sans parler de punitions préliminaires, allant de diverses tortures à l'empalement. ${ }^{1+}$

Dari kesaksian kedua pelancong tersebut, maka dapat kita ketahui bahwa hukuman perzinaan ada dua macam: 1. hukuman mati bagi lelaki, 2. hukuman menjadi budak bagi perempuan. Jika kita perhatikan secara seksama jenis hukuman tersebut, nampak hukuman yang diterapkan adalah hukum adat atau kebiasaan setempat, dan sama sekali bukan hukum Islam. Dugaan ini diperkuat oleh kesaksian pelancong tersebut yang tidak menyebutkan: pertama status pelaku: menikah atau belum menikah; sebab dalam hukum Islam hukuman bagi keduanya berbeda; Kedua, cara pelaksanaan hukuman zina itu, apakah dirajam, dipancung, atau jenis hukuman lainnya. Dengan demikian kita masih kesulitan untuk mengatakan bahwa praktik hukuman tersebut berdasarkan hukum Islam. Dari sini, dapat ditarik kesimpulan bahwa hukuman pidana zina di Tiku saat itu bukanlah hukum pidana Islam yang dilaksanakan, tetapi lebih pada pemberlakuan hukum adat saat itu.

Baru pada masa sultan ke-3 Alaudin Riayat Syah al-Kahhar (1537-1571), hukuman zina di Aceh dapat diketahui dengan jelas, yaitu dihukum dengan hukum rajam. Berdasarkan sumber dari India, Rawdla al-Thâhirin, menyebutkan bahwa hukum rajam telah dipraktikkan di Kesultanan Aceh. Keterangan ini berdasarkan seorang pelancong India Thâhir Muhammad Sabzwari yang berkunjung ke Aceh. Dia menceritakan bahwa dua orang dijumpai telah berzina, pada tahun 1550, dengan status masing-masing telah menikah dihadapkan ke Sultan yang kemudian menghukum mereka dengan hukuman mati. Kedua orang itu dibawa ke alun-alun, lalu dirajam hingga mati ${ }^{15}$.

35 .

${ }^{13}$ Bernard Dorleans, "Les Francais et L'Indonesie", Paris: Kailash, 2001, hal. 33-

14 Dorléans, Op. Cit., hal. 35. Mereka juga mengatakan "La chasteté était strictement imposée à sumatra. La prostitution était une pratique inconnue..." (Kesucian benar-benar sangat dijaga di Sumatra, pelacuran adalah perilaku yang tak dikenal...)

${ }^{15}$ Muzaffar Alam \& Sanjay Subrahnyaman, Southeast Asia as Seen Froum Mughal India, "Archipel 70", Paris, 209-237, hal. 225-226. 
Jika kita perhatikan jenis hukuman tersebut, maka tampak bahwa Sultan al-Kahhar menerapkan hukum pidana syariah bagi pezina muhshan (telah menikah), yaitu dirajam hingga mati. Menurut hukum Islam Sunni (Hanafi, Maliki, Syafi'i dan Hanbali) bahwa hukuman bagi pezina muhshan ialah dirajam dengan batu hingga mati ${ }^{16}$. Hukuman rajam berdasarkan hadis Nabi yang diriwayatkan oleh Bukhari ${ }^{17}$ dan Muslim ${ }^{18}$, “...Jika dia berzina, maka rajamlah!” Namun hukuman rajam itu tidak berlangsung lama. Ketika Sultan al-Kahhar wafat, maka kebijakan hukumannya pun ikut pergi bersamanya.

Perkembangan selanjutnya terjadi pada masa sultan ke-10. Pada masa Sultan Alauddin Riayat Syah al-Mukammil (1588-1604), ia menerapkan hukuman zina dengan cara yang lain. Berdasarkan kesaksian John Davis, seorang Inggris yang datang ke Aceh, pada tahun 1599, ia mengatakan bahwa sultan ini menerapkan hukuman sesuai dengan keinginan dan sekehendak hatinya. ${ }^{19}$ Davis menulis lebih lanjut:

The kings will is their law. For it seem there is no freeman in the land: for the life and goods of all is at the kings pleasure. He will make no offenders happie by death, by cut off their hands and feet, and banish them to an isle named Polo Wey. If he put any to death, the elephants tear him to pieces, or they drive a stake into his fundament and so he

${ }^{16}$ Muhammad Ibn Idrîs al-Šafi'i, "al-Umm", ed. Muhammad Zuhrî al-Nağğâr, VII vols, Beirut: Dâr al-Ma'rifa, t.t., vol. VI hal. 133 dan 154-155, Sahnûn Ibn Sa'ad al-Tanûhî, alMudawwana al-Kubrâ Li al-Imâm Mâlik, ed. 'Ali Ibn 'Abd Rahmân al-Hâšimi, XI vols, Kairo: Dâr al-Nashr, t.t., vol. XI, hal. 62. Muwaffaq al-Dîn Ibn Qudâmah, al-Mugnî, XIII vols, Beirut: Dâr al-Kitâb al-'Arabiy, 1983/1403, vol. X, hal. 120-121, Šamsuddîn al-Sarahsî, alMabsût, XXX vols, Beirut: Dâr al-Kutub al-'Ilmiyya, 1994/1414, vol. IX, hal. 39.

17 Abu 'Abd Allah Muhammad Ibn Isma'il al-Bukhari, "Sahih al-BukhariI", ed Mustafa Dib al-Buga. VI vols. Vol. VI. Beirut:Mu'assasat al-Khidmat al-Tibâ'iyyat, 19801982, vol. VI, hal. 2399, hadis no. 6430, dan untuk hadis yang lain no. 6427-9, hal. 2398-9.

${ }^{18}$ Abu al-Husayn Muslim, "Sahih Muslim", ed. Muhammad Fu'ad 'Abd al-Baki. V vols. Vol. III. Kairo: Mustafa al-Babi al-Halabi, 1955, hal. 1316-7, hadis no. 1690-1, dan untuk hadis yang lain, lihat hal. 1318-26.

19 John Davis, "A Brief Relation of Master John Davis", dalam "Purchas His Pilgrimes", ed. Samuel Purchas, book III, hal. 116-124, London: William Stansby, 1625, vol. I, hal. 132. 
dies. There are gaols and many fettered prisoners that go about the town. ${ }^{20}$

Gambaran dan bentuk hukuman zina lebih jelas diberikan oleh François Martin de Vitré, seorang pelancong Prancis, yang tinggal di Aceh. Ia tiba di Sumatra tanggal 17 Juli $1602^{21}$ dan menetap di Aceh dari tanggal 24 Juli hingga 20 November $1602^{22}$. Ketika tiba di Aceh, Martin de Vitré pergi menghadap Sultan Alauddin al-Mukammil ${ }^{23}$. Berdasarkan kesaksiannya, ia menulis aneka ragam bentuk hukuman zina di Aceh:

...Les deux personnes qui ont commis l'adultère sont présentées aux éléphants qui les tuent par le commandement de celui qui les conduit. ${ }^{24}$ Aux hommes adultères, on leur coupe les parties honteuses et aux femmes le nez ou bien on leur crève les yeux. ${ }^{25}$

Berdasarkan kesaksian François di atas, maka hukuman zina pada masa al-Mukammil itu ada dua: Pertama, lelaki atau perempuan yang berzina dibunuh oleh gajah dengan cara diinjak-injak atau badannya ditarik hingga hancur berkeping-keping. Kedua, bagi lelaki yang berzina dipotong kemaluannya, sementara bagi wanita dipotong hidungnya dan dicongkel kedua matanya. Jika diperhatikan secara seksama, nampak bahwa hukuman pada masa Sultan al-Mukammil berdasarkan hukum adat atau yang lebih tepatnya hukum yang sesuai

${ }^{20}$ Davis, Op. Cit., vol. I., hal. 132.

${ }^{21}$ Il tinggal di Sumatra dari 18 Mei 1601 hingga 13 Mei 1603, tetapi baru ke Aceh pada tanggal tersebut dan kemudian menetap untuk beberapa saat. François Martin de Vitré, "Description du premier voyage fait à Sumatra par les Français en l'an 1603 contenant les moeurs, lois, façons de vivre, religions \& habitudes des Indiens," dans Voyage de Pyrard de Laval aux Indes Orientales (1601-1611), ed. Xavier de Casto, hal. 907-932, Paris : 1603, cetak ulang Chandeigne 1998, hal. 916.

${ }^{22}$ Denys Lombard, "Martin de Vitré Premier Breton à Aceh (1601-1603)", Archipel 54 (1997): hal. 3-12, hal. 3.

${ }^{23}$ Lombard, Op. Cit., hal. 7, lihat juga komentar de Xavier de Casto, Martin de Vitré, Op. Cit., hal. 964.

\footnotetext{
${ }^{24}$ de Vitré, Op. Cit., hal: 921.

${ }^{25}$ de Vitré, Op. Cit., hal. 922.
} 
dengan kehendak dan keinginan penguasa yang saya sebut sebagai "hukum sultan".

Selanjutnya pada masa sultan ke-12, yaitu Iskandar Muda (16071636), bentuk hukuman berzina berubah lagi. William M. Marsden menulis mengenai hukuman zina:

Un homme convaincu d'adultère, trouve rarement des protecteurs parmi ses amis; on le livre ordinairement entre les mains des amis et des parents du mari offensé, qui le conduisent dans un vaste champ, où formant un grand cercle; ils le placent au milieu. Alors un de ses parents lui remet une arme fort grande appelée gedoobong. Muni de cet instrument, le coupable cherche à se faire un passage à travers ceux qui l'entourent, et à s'échapper; s'il y parvient, il est désormais à l'abri de toute poursuite. Mais il arrive ordinairement qu'il est sur -le champ- mis en pièces. Dans ce cas, ses parents enterrent son cadavre comme ils enterreraient un vison mort, ne voulant point le recevoir dans la maison, ni lui faire les funérailles accoutumées. ${ }^{26}$

L'adultère est puni par une amende mais il est rare et les poursuites pour ce sujet encore moins fréquentes. Le mari ou cache sa honte, ou en tire vengeance de sa propre main. $^{27}$

Berdasarkan tulisan Marsden, maka pada masa Iskandar Muda, ada tiga macam hukuman zina:

Pertama, seorang lelaki yang diketahui berbuat zina akan diletakkan di tengah lingkaran yang dikelilingi oleh orang tua suami dari perempuan yang dizinai dan teman-temannya. Si lelaki pezina diberi senjata untuk melawan. Dia harus melwati orang-orang yang mengelilinginya untuk melarikan diri. Tapi usaha ini jarang berhasil. Si pelaku biasanya mati terpotong-potong oleh senjata orang-orang yang mengelilinginya. Setelah meninggal, orang tua lelaki pezina menguburkannya seperti menguburkan seekor banteng mati. Mereka

${ }^{26}$ Willian M. Marsden, "History de Sumatra", pent. M. Parraud. II vols. II. Paris: Chez Buisson, 1788, h. 231-3 dstnya, lihat juga edisi aslinya William Marsden, "The History of Sumatra", Kuala Lumpur: Oxford Univesity Press, 1966 (1811), h. 404-5.

${ }^{27}$ Marsden (versi Prancis), Op. Cit., hal. 233 passim. 
tidak mau menerima jenazah anaknya di rumah mereka. Tidak ada pemakaman yang layak.

Kedua, si pezina dihukum denda. Dia harus membayar sejumlah uang kepada keluarga korban, tetapi hukuman ini sangat jarang. Ketiga, Jika istri ketahuan berzina, maka suaminya akan membunuh sendiri si lelaki yang menzinai istrinya, atau ia diam menutup rapat aib tersebut. Dari ketiga bentuk hukuman ini, nampak jelas bahwa hukuman tersebut berasal dari hukum adat yang berlaku saat itu atau "hukum sultan."

Setelah pemaparan fakta sejarah di atas, nampak bahwa hukuman zina di Aceh sepanjang abad XVI-XVII berdasarkan hukum adat atau lebih tepat lagi apa yang saya sebut sebagai "hukum sultan" yaitu hukuman berdasarkan selera dan keinginan sultan yang berkuasa. Hukum pidana Islam untuk zina, berupa rajam, hanya ditemukan pada masa sultan al-Mukammil, selain itu tidak ada. Hal ini jauh dari bayangan kita yang selalu menduga bahwa kesultanan Aceh, sebagai pemerintahan Islam, mesti menerapkan hukum Islam. Ternyata, hal itu sama sekali jauh dari fakta sejarah yang ada.

Ketika saat ini, Pemda NAD mengeluarkan Qanun No. 14/2003 yang melarang zina dengan dalih telah sesuai dengan hukum pidana Islam, masalahnya adalah apakah benar-benar diterapkan?

Kasus terakhir di Aceh menyangkut perzinahan pasangan sejoli antara seorang anggota wilayah hisbah atau polisi syariah Raihanuddin Lubis (34 th) dengan Magdalena (17 th) menguap begitu saja, tanpa ada kejelasan hukuman. Setelah tertangkap basah sedang berzina di kamar mandi umum pada 17 April 2007 oleh patroli syariah, mereka hanya dihadapkan ke Kepala Desa dan kemudian dinikahkah di Masjid sehari setelah kejadian itu, 18 April 200728. Jika benar konsisten, seharusnya Mahkamah Syariah Aceh tidak tebang pilih dalam penerapan syariah tersebut. Mereka semestinya mendapatkan hukuman cambuk berdasarkan Peraturan yang dikeluarkan Gubernur NAD No. 10/2005. Kalau tidak diterapkan, maka hal ini akan berdampak buruk di kemudian hari. Ketidakpuasaan masyarakat akan penerapan syariah yang pilih kasih ini sudah mencuat dengan berbagai aksi demontrasi yang menuntut pemberlakuan syariah atas pejabat-pejabat yang bersalah. Jika Pemda NAD tidak serius, maka penerapan syariah yang bertujuan menciptakan keamanan dan ketenteraman masyarakat,

${ }^{28}$ Binalnya Polisi Syariah, dalam tayangan FAKTA edisi Selasa 1 Mei 2007 jam 23.00-23.25 WIB di ANTEVE. 
malah akan akan menjadi bom waktu di masa yang akan datang akibat tumpukan kekecewaan masyarakat.

\section{B. Pencurian}

Ada aneka ragam bentuk hukuman pencurian pada masa kesultanan Aceh. Bentuk hukuman pertama kali diketahui pada masa Sultan al-Kahhar, menurut sumber India Rawdla al-Thâhirîn ${ }^{29}$, adalah potong tangan. Menurut sumber tersebut, hukuman potong tangan berlaku bagi semua bentuk kejahatan atau tindak kriminal. Jadi, pencurian dihukum dengan potong tangan. Saya menduga pada awalnya hukuman ini adalah hukuman bagi pencuri yang diterapkan oleh hukum Islam ${ }^{30}$. Tetapi, ternyata hukuman ini berlaku bagi semua tindak kejahatan. Artinya, bukan saja pencurian yang dihukum potong tangan, tetapi semua kejahatan dihukum dengan potong tangan. Dengan demikian, hukuman tersebut adalah hukum adat atau kebiasaan setempat, dan bukan hukum Islam.

Bentuk hukuman pencurian nampak semakin jelas pada masa Sultan al-Mukammil, sultan ke-10. François Martin de Vitré pada tahun 1602 menulis mengenai hukuman mencuri berdasarkan apa yang dia lihat di Aceh saat itu:

Pour un larcin de quelque peu que ce soit, on leur coupe une main pour la première fois, et s'ils y retournent, on leur coupe les pieds et l'autre main. ${ }^{3 l}$

Dari kesaksian François di atas, kita mengetahui bahwa hukuman bagi pencuri kecil dipotong tangannya. Jika dia mengulangi lagi perbuatannya, maka dipotong kaki dan tangannya yang lain.

\footnotetext{
${ }^{29}$ Alam \& Subrahnyanam, Op. Cit. hal. 226.
}

${ }^{30}$ Alquran menetapkan hukum potong tangan bagi pencuri baik lelaki maupun perempuan, QS al-Maidah/5:38. Dari ayat ini kemudian para ahli hukum Islam (fuqahâ') sepakat menyatakan bahwa hukuman pencuri adalah potong tangan. Jika pencuri mengulangi perbuatannya untuk yang ketiga dan keempat kalinya, maka kakinya dipotong menurut Maliki, Syafi'i dan Hambali. Lihat Abd Rahmân al-Jazîrî, Kitab al-Fiqh 'ala Madzhâb al Arba'ah, V vol., Beirut: Dar al-Fikr 1987 M./1406 H., h. 153-4, Abû al-Walîd Muhammad Ibn Rushd, Bidayat al-Mujtahid Wa Nihayat al Muqtasid, II vol., Beirut: Dar al-Fikr, t. t. vol. II, h. 334. Sayid Sabiq, Figh Sunnah, III vol., Kairo:tanpa penerbit, 1988/1409, vol II, h. 410. Muhammad Salim Al-'Awwa, Fi Usûl al-Nizâm al-Islâm, Kairo: Dar al-Ma'arif, 1979, h. 170

${ }^{31}$ de Vitré, Op. Cit., hal. 922. 
Kesaksian François itu diperkuat oleh kesaksian orang-orang Belanda. Satu tahun setelah kesaksian François, pada tahun 1603 satu rombongan kapal dari Belanda yang dipimpin Wybrandt van Waarwyk datang ke Aceh. Ia memberikan kesaksian bahwa tindak kriminal di Aceh dihukum dengan sangat berat. Van Waarwyk menulis:

La justice qu'on y rend est fort-sévére, et la punition des crimes rude et terrible. Pour de très petits sujets on y fait couper les piés \& les mains. Les hollandois y voioient quantité de personnes qui n'avoient qu'un pié et une main, et le bout de la jambe était dans une espèce de jatte creuse qui y était attachée. Le bras était apuîe sur une potence qui y était aussi liée, \& qui soutenait la personne. Ces supplices ne regardent pas seulement le petit peuple, ils ont aussi pour les grands seigneurs. Car on vit à la cour même, le beau-fils du roi, fils de la mére du jeune roi, à qui, par punition, l'on avait fait couper le nez, les oreilles, \& la lévre-de-dessus. ${ }^{32}$.

Berdasarkan kesaksian Van Waarwyk di atas, kita mengetahui bahwa hukuman di Aceh untuk masalah yang kecil saja adalah potong tangan dan potong kaki. Oleh karena itu, banyak sekali orang yang hanya mempunyai satu tangan dan satu kaki sebagaimana disaksikan oleh Van Waarwyk dan orang-orang Belanda lainnya. Mereka menutup dengkulnya yang terpotong dengan mangkok yang diikatkan kepada dengkul itu dan menggunakan tongkat dari bambu untuk menopang badan mereka agar dapat berjalan. Hukuman potong tangan dan kaki (hingga dengkul) ini berlaku bagi semua jenis kejahatan dan berlaku bagi semua orang: rakyat biasa atau bangsawan. Bahkan, keponakan Sultan sendiri dihukum dengan potong hidung, kuping, dan bibir atas. Tidak diketahui kesalahan apa yang dilakukan oleh keponakan Sultan sehingga dia dihukum sedemikian rupa.

Atas dasar kesaksian Van Waarwyk, nampak bagi kita bahwa ada lima macam hukuman badan yang berlaku di Aceh, yaitu potong tangan, kaki, hidung, kuping, dan bibir. Kemungkinan besar hukuman ini berasal dari hukum adat atau kebiasaan setempat. Hukum potong

${ }^{32}$ Wybrandt van Waarwyk, "Voiage de quinza vaisseaux hollandois commandez par l'amiral Wybrandt van Waarwyk pour la com pagnie d'octroiindesorientales formee dans les provinces unies", Dalam Recueil de voyages qui ont servi a l'etablissement et aux progress dela Compagnie des indes Orientales, forme dans les Provinces Unies des Pays-Bas, edited by Constantin de Renneville, V vol, h. 1-107, Amsterdam: E. Roger, 1702, hal. 594-5. 
tangan dan kaki memang dijumpai dalam hukum Islam, tetapi tidak jelas apakah mereka dihukum seperti itu karena mencuri atau karena melakukan tindak pidana yang lain. Bahkan, dikatakan dalam tulisan Van Waarwyk itu, bahwa hukuman tersebut berlaku bagi semua bentuk kejahatan. Dengan demikian, kelima bentuk hukuman itu berasal dari hukum adat, atau hukum 'sultan': hukuman yang ditentukan secara sewenang-wenang dan seenak selera penguasa.

Nampaknya kasus pencurian di Aceh saat itu sangat parah, sehingga penguasa harus menerapkan hukuman begitu keras, bahkan cenderung kejam. Mereka yang tidak mempunyai tangan dan kaki lagi, menurut Van Waarwyk, dibuang ke Pulau Wey ${ }^{33}$. Pembuangan ini dilakukan, jika para pencuri masih mencuri lagi walau tangan dan kaki mereka sudah dipotong. Hukuman pembuangan sama dengan hukuman takzir dalam hukum islam, yaitu taghrîb atau pengasingan ke suatu tempat. Namun, saya tidak tahu pertimbangan hukuman inf berdasarkan apa: hukum adat atau hukum Islam?

Hukuman potong tangan bagi pencuri dilegalkan di dalam Undang-Undang Aceh yang dibuat pada masa Sultan Iskandar Muda ${ }^{34}$. Pasal 33 UU Aceh menyebutkan bahwa kepala kampung harus menghukum pencuri: si pencuri harus mengembalikan barang curiannya atau menggantinya. Jika pencuri itu kabur dari wilayah Kesultanan Aceh, maka dia tidak dapat kembali ke tempat tinggalnya (pasal 34), dan jika dia kembali, maka akan ditangkap dan dipotong tangannya (pasal 35$)^{35}$.

Jika dikaji isi dari Pasal 35 UU Aceh tersebut nampak bahwa UU ini merujuk pada hukum Islam. Alquran menyatakan dengan sangat jelas mengenai hukuman potong tangan ini bagi pencuri, yaitu QS. AlMâ'idah/5:38. Berdasarkan ayat ini, para ahli hukum Islam sepakat

${ }^{33}$ Van Waarwyk, Op. Cit., hal. 599.

${ }^{34}$ K. F. H. Van Langen,'De Inrichting Van Het Atjehsche Staatbestuur Onder Het Sultanaat, Bijdragen tot de Taal-Land-ben Volkkenkunde V, no. III (1888): hal. 381-471, hal. 939.

35 UU Aceh terdapat dalam bab tambahan pada Langen, Op. Cit., h. 440-1, Bandingkan dengan edisi yang telah diindonesiakan dalam Tuanku Abdul Jalil, "Adat Meukuta Alam", Banda Aceh: Pusat Dokumentasi Dan Informasi Aceh, 1991,h. 22. Lihat juga edisi manuskrip UU Aceh yang diindonesiakan dan ditulis tangan oleh Tengku Mohammad Noerdin, Asisten Snouck Hurgronje, "Undang-Undang Aceh", di Perpustakaan Nasional, kode M1. 533, 32 hal. Jakarta, 1927. 
bahwa hukuman mencuri adalah potong tangan ${ }^{36}$. Lalu, hukum Islam madzhab apa yang dirujuk oleh UU Aceh ini? Hanafi berpendapat jika pencuri telah mengembalikan barang curiannya, atau mengganti barang curian yang telah rusak, maka hukum potong tangan tidak dijatuhkan. Adapun menurut Syafi'i dan Hanbali hukuman tetap harus diterapkan, karena hukuman potong tangan tetap merupakan hak Allah, sementara pengembalian atau penggantian barang curian adalah hak manusia ${ }^{37}$. Dengan demikian, Pasal 33 UU Aceh ini bersesuaian dengan hukum Islam madzhab Hanafi. Tetapi, kita tidak tahu apakah pembuat UU ini mengerti aneka ragam pendapat dalam hukum Islam, atau isi pasal itu secara kebetulan sama. Hukuman potong tangan yang telah disahkan ini benar-benar dipraktikkan sebagaimana beberapa sumber Eropa memberi kesaksian, seperti di bawah ini.

Laksamana Pierre Willemsz Verhoeven yang berada di Aceh pada tanggal 10 November 1608 menulis bahwa banyak sekali hukuman badan yang diberlakukan di Aceh:

Il y a encore d'autres supplices. On coupe aux prévenus les mains, ou les piés, ou bien une main et une pie ou les parties naturelles, et on les envoie dans l'isle puloai ou pulo wai, qui n'est presque peuplée de pareilles gens. On en voit aussi à Achem, qui mandient leur pain. ${ }^{38}$

Berdasarkan kesaksian Verhoeven di atas, maka kita mengetahui bahwa penguasa menjalankan hukuman fisik, yaitu mereka memotong tangan, kaki atau salah satu tangan dan satu kaki dan organ intim pelaku kriminal. Hukuman potong tangan dan kaki mungkin saja hukuman bagi pencuri. Tetapi kita tidak mengetahui apakah pelaksanaan hukuman pada masa sultan ke-12 sesuai dengan hukuman yang diminta oleh syariah atau hanya mengikuti seleranya saja. Tetapi yang pasti hukuman potong organ intim tidak pernah ada dalam

${ }^{36}$ al-Ǧazîrî Op. Cit., vol. V, hal. 153-154, Sâbiq, Op. Cit., vol.II, hal. 410, Ibn Rušd, Op. Cit., vol. II, hal. 334.

37 Hervé Bleuchot, "Droit Musulman", II vols, Aix-en-Provence: Presses Universitaires d'Aix Marseille, 2002, vol. II, hal. 691.

${ }^{38}$ Pierre Willemsz Verhoeven, "Voyage de l'amiral Pierre Willemsz Verhoeven aux indes orientales", di dalam "Recueil de voyages qui ont servi à l'établissement et aux progrès de la Compagnie des Indes Orientales, formée dans les Provinces-Unies des Pays-Bas", disunting oleh Constantin de Renneville, V jilid, jilid IV, hal. 1-107. Amsterdam: E. Roger, 1705, hal. 63 . 
hukum Islam, karena itu dapat dipastikan bahwa hukuman itu adalah hukum adat atau hukum sultan.

Saksi berikutnya ialah Pierre van Den Broeck, orang Belanda yang datang ke Aceh untuk berdagang dan tiba pada bulan Maret 1618. Ia menulis kesaksiannya itu:

Ses sujets le redoutent beaucoup à cause des tirannies qu'il exerce sur eux, inventant sans cesse de noveaux genres de mort et d'autres suplices pour avoir le plaisir de les tourmenter. S'il arrive qu'un homme ou une femme fasse la moindre faute, ou seulement quelque chose qui lui deplaise, il faut quelquefois que toute sa race en patisse. Il ne se passe guéres de jours qu'il ne fasse suplicier quelqu'un. Faire couper le nez, les mains, ou les jambes, n'est qu'un jeu à quoi il s'éxerce ordinairement puis il envoie les mutiles en éxil dans l'ile pulo wai vis-à-vis d'Achin. ${ }^{39}$

Dari kesaksian van Den Broeck ini, kita mengetahui bahwa rakyat Aceh sangat takut kepada rajanya (Iskandar Muda) yang sangat tiran. Ia sering menghukum mati orang dan menyiksa orang untuk kesenangan dirinya. Ia menghukum orang walaupun kesalahan yang dibuatnya sangat kecil. Ia menghukum orang dengan memotong tangan, kaki dan lutut. Hukuman potong tangan dan kaki kemungkinan adalah hukuman pencuri sebagaimana dituntut oleh hukum Islam. Adapun hukum potong lutut tidak terdapat dalam hukum Islam.

Saksi mata selanjutnya adalah Agustin de Beaulieu, seorang Prancis yang melakukan misi dagang di Aceh selama dua tahun (16201622). Ia mengatakan bahwa rakyat Aceh mengikuti hukum Islam ${ }^{40}$. Tetapi apakah hukuman pencurian mengikuti hukum Islam? Mengenai hukuman pencuri, Beaulieu menulis bahwa hukuman bagi pencuri

${ }^{39}$ Pierre Van Den Broeck, "Voyages de Pierre Van Den Broeck au Cap Vert, à Angola et aux Indes Orientales", dalam "Recueil de voyages qui ont servi à l'établissement et aux progrès dela Compagnie des Indes Orientales, formée dans les Provinces-Unies des PaysBas", disunting oleh Constantin de Renneville, V jilid, jilid IV (mikrofilm), hal. 306-473, Amsterdam: E. Roger, 1705, hal. 426.

${ }^{40}$ Augustin de Beaulieu, "Memoires d'un voyage aux indes orientales 1619-1622", ed. Denys Lombard, Paris: Maisonnueve \& Larose,1996, hal. 200. Bandingkan dengan cetakan pertama dari catatan Augustin de Beaulieu pada "Memoires du voyage aux indes orientales du general Bealieu Dresse par Luy-meme," dalam "Relations de Divers Voyage Curieux Qui N'Ont Pas Este Publiees", ed. M. Thevenot, hal 1-128, Paris: Sebastien Cramosy, 1664-1666 
kecil adalah dicambuk ${ }^{41}$. Sementara bagi pencurian besar, menurut William Marsden ada 2 macam: (1.) jika pencurian dilakukan di jalan besar atau di rumah dengan cara menjebol atau merusak, maka hukumannya dibunuh dengan cara disulak (sebuah bambu runcing dimasukkan lewat anus dan keluar lewat mulut) lalu mayatnya dipajang selama beberapa hari; (2.) Jika korban pencurian adalah seorang imam, maka pencurinya dibakar hidup-hidup ${ }^{42}$.

Ketika Iskandar Muda wafat, menantunya Iskandar Thani menggantikannya. Hukuman yang berlaku pada masa Iskandar Thani (1636-1641, sultan ke-13, tak banyak berubah, kecuali ia melarang hukuman bercelup minyak dan menjilat besi. Bustanu 's-Salatin menyatakan:

...Dan ia-lah melakukan hukum Allah dan mengeraskan shari'at Nabi Muhammad Rasulu'llah s.m. Dan ia-lah mendirikan masjid di Bandar Daru's-Salam bernama Baitu'l-Mushahadah, dan ia-lah yang melarangkan berchelup minyak dan berjilat besi... ${ }^{13}$

Sumber kita kali ini adalah Peter Mundy, orang yang datang ke Aceh pada 19 April 1937 dan diterima hangat oleh Sultan Iskandar Thani di istananya ${ }^{44}$. Peter Mundy menulis:

Justice executed here with cruelty on malefactors, viz, to some cutting off both hands and feet, others hands or feet only; to others their noses, their lipses, privities and thus dismembered, mangled and disfigured, they are let go to seek their staking alive, sawing asunder alive, cutting in peeces, throwing to elephants to be by them dismembered and torne in pieces. ${ }^{45}$ 404-5.

${ }^{41}$ Beaulieu, Op. Cit., hal. 202.

${ }^{42}$ Marsden, Op. Cit., hal. 231-3, lihat juga versi Inggrisnya, Marsden, Op. Cit., hal.

${ }^{43}$ ar-Raniri (Iskandar), Op. Cit., hal. 44-45.

${ }^{44}$ Peter Mundy, "The Travel of Ppeter Mundy in Europe and Asia 1608-1667", ed R. C. Temple, V vols, Vol. III, Part:1, Travels in England, Western India, Achin, Macao \& The Canton River 1634-1637, London: The Hakluyt Society. 1919, hal. 117.

${ }^{45}$ Mundy, Op. Cit., vol. III, bagian I, hal. 135. 
Berdasarkan kesaksiannya, Mundy melihat sendiri hukuman yang dipraktekkan di masa Iskandar Thani, yaitu potong tangan, kaki, hidung, bibir, organ intim. Badan dirobek dan dibuat cacat, digergaji hidup-hidup hingga hancur terpotong kecil-kecil, dirobek dan dikoyakkoyak oleh gajah ${ }^{46}$. Mundy kembali menulis kesaksiannya tentang hukuman di Aceh, ketika ia datang kembali ke Aceh pada bulan Februari 1638 dari Malaka: ${ }^{47}$

In the castle greene were alsoe 3 little low lodges off boards full of long miles or spikes, the points in wards, soe thatt a man can neither stand nor leave. Here some offenders are putt and kept till they are called forth to receive liberty or punishment, which are usually performed with extremity as death by several waies, cutting of hands or feett (or both), noses, lippes or privities or all. To some more, to some less and then are left go of these maymed and dismembered people we saw about the towne, the stumpes if their legges put into big bamboes or canes, wherewith they goe as on stiltts. This their old manner of government which they are accustomed unto and must be contented with all, not knowing how to help it. ${ }^{48}$

Dari kesaksiannya, Peter Mundy menyaksikan bahwa Sultan Iskandar Thani menghukum orang dengan hukuman potong tangan, kaki, bibir dan organ intim, selain hukuman penjara. Mundy sendiri banyak melihat orang-orang di jalan yang tidak memiliki tangan dan kaki lagi. Mereka menopang badan mereka dengan bambu.

Dari berbagai bentuk hukuman tersebut di atas hanya dua yang sesuai dengan hukum Islam, yaitu hukuman potong tangan dan kaki yang berhubungan dengan pidana pencurian. Adapun hukuman lainnya yaitu potong hidung, bibir, organ intim, tubuh dirobek, digergaji dan diinjak gajah merupakan hukuman yang sama sekali tidak ada dalam hukum Islam. Jadi dapat dipastikan, hukuman itu berdasarkan hukum adat yang berlaku saat itu atau hukum sultan.

${ }^{46}$ Mundy, Op. Cit., vol. III, bagian 1, hal. 135.

${ }^{47}$ Peter Mundy, "The Travel of Peter Mundy in Europe and Asia 1608-1667", ed R. C. Temple, V vols., Vol. III, Part: II, Travel in Achin, Mauritius, Madagaskar and St. Helen 1638, London: The Hakluyt Society, 1919, hal. 939.

${ }^{48}$ Mundy, Op. Cit., vol. III, bagian II, hal. 331. 
Setelah Iskandar Thani wafat, istrinya yang juga putri Iskandar Muda, Tajul Alam Safiyatuddin menggantikannya. Hukuman pencurian pada masa Safiyatuddin (1641-1675 M.) ada dua macam: pencurian terhadap milik kesultanan dan milik umum. Jika seorang mencuri sesuatu milik sultan, maka hukumannya adalah hukuman mati. Berdasarkan kesaksian Pieter Willemsz, pegawai Belanda yang berada di Aceh pada tahun 1642, yang melaporkan bahwa Sultanah Safiyatuddin menghukum mati seorang penduduk Aceh yang telah mencuri seekor kuda milik kerajaan. Menurut hukum Islam, pidana pencurian diganjar dengan hukuman potong tangan bukan hukuman mati. Jadi, hukuman pencurian di Aceh masa Safiyatuddin tidak berdasar hukum Islam, tapi berdasar hukum adat atau hukum sultan.

Pada masa Safiyatuddin pencurian umum dibagi menjadi: pencurian kecil dan pencurian besar. Kita mengetahui bentuk hukuman untuk keduanya berdasarkan kesaksian Caspar Schmalkalden, seorang Jerman yang berkunjung ke Aceh. Pada 28 September 1647, Schmalkalden menulis:

Auf achem habe ich einen Mann, wie der vorige Abriß ausweiset, gesehen, welcher weder Hände noch füße hatte. Er konnte dennoch gehen, stehen, tanzen, auch seinen stock in die Höhe schleudern und denselben wieder fangen. Er war, wie von andern Malayern erzählet wurde, wegen oft begangenen Diebstahls also gestrafet worden. Denn um geringen Diebstahls willen warden nich allein gemeinen, sondern auch wohl Edelleuten die Nasen und Ohren abgeschnitten, sondern auch, wennder Diebstahl groß ist, Hände und Füße, wie diesem geschehen, abgehauen. ${ }^{49}$

Berdasarkan kesaksiannya, ia banyak menjumpai orang yang tidak punya tangan dan kaki di jalan-jalan di Aceh, tetapi mereka tetap bisa berdiri, berjalan bahkan berjoget dengan bantuan tongkat bambu. Schmalkalden diberitahu oleh orang-orang bahwa mereka seperti itu karena mencuri. Orang-orang Aceh mengatakan kepada Schmalkalden bahwa hukuman pencurian kecil adalah dipotong hidung dan kupingnya. Adapun pencurian besar hukumannya adalah dipotong tangan dan kakinya ${ }^{50}$.

${ }^{49}$ Caspar Schmalkalden, "Die wundersamen reisen des Caspar Schmalkalden nach West- und Ostindien 1642-1652"c, édité par Wolfgang Joost, Weinheim: Acta Humaniora, 1983, hal. 112-113. 
Untuk memperkuat apa yang disaksikan, Schmalkalden menggambar seorang Aceh yang dipotong tangan dan kakinya dan orang yang digambar itu mengatakan bahwa ia dipotong tangan dan kakinya karena mencuri berulang kali:

\section{Diebstahl hat mich viermal in gross Unglück gestürtzet/Dafür mir meine Händ und Füss sind abgestürzet/Nun geh ich auf die Strass, versuche gross und klein/Zu meiner Dürftigkeit behülflich mir zu sein. ${ }^{\text {sI }}$}

Dari sini nampak bahwa hukuman potong tangan dan kaki untuk pidana pencurian mungkin telah sesuai dengan apa yang diminta oleh hukum Islam, walaupun saya tidak tahu apakah sultanah tersebut menerapkannya atas dasar hukum Islam atau hukum adat.. Adapun hukuman potong hidung dan kuping tidak ada dalam hukum Islam. Kemungkinan hukuman itu berdasarkan hukum adat setempat atau hukum sultan.

Ketika Safiyatuddin mangkat, Sultanah Nurul Alam Nakiyatuddin (1675-1678) menggantikannya. Hukuman pencurian pada masa Nakiyatuddin tidak banyak berubah, yaitu hukuman mati dan hukuman potong tangan dan kaki tetap berlaku. Berdasarkan kesaksian Thomas Bowrey, laksamana Inggris yang bertugas di India yang berkunjung di Aceh dan tinggal di Aceh beberapa bulan, kita mengetahui hukuman pencuri pada masa Nakiyatuddin. Menurut Bowrey, hukuman di Kesultanan Aceh sangat kejam, khususnya hukuman pencuri yang diganjar lebih kejam dengan hukuman pembunuhan:

The laws of this kingdome are very severe in many respects, especially for theft, more cruel then for murder, for then 'tis death without any tediousnesse, but for theft it cometh gradually on with great affliction. ${ }^{52}$

${ }^{50}$ Schmalkalden, Op. Cit, hal. 114.

${ }^{51}$ Schmalkalden, $O p$. Cit., hal. 144. (terjemahan bebas: Mencuri hingga empat kali telah membuatku sangat menderita/Inilah alasan mengapa mereka memotong tangan dan kakiku/Dan sekarang saya berjalan-jalan di jalanan, dengan berbuat seperti ini sehingga orang dewasa dan anak kecil/Selamat dari kemalangan seperti saya).

52 Thomas Bowrey, "A Geographical Account of Countries Round The Bay of Bengal 1669 to 1679”, ed. R. C. Temple, 1993 ed., Cambridge: Hakluyt Society, 1905, hal. 315. 
Hukuman ini dijatuhkan bagi mereka yang mencuri: pertama, barang yang harganya sama dengan seekor sapi atau kerbau ${ }^{53} ; k e d u a$, mencuri barang perusahaan milik orang asing. Bowrey melaporkan hukuman mati yang diputuskan oleh orangkaya, hakim di Aceh, bagi seorang yang tertangkap mencuri barang tekstil milik perusahaan Inggis ${ }^{54}$.

Hukuman potong tangan dan kaki dijatuhkan jika seorang mencuri barang yang harganya lebih dari 154 gram emas. Pada pencurian pertama, ia dihukum potong tangan. Jika mencuri kedua kalinya, kakinya dipotong. Dan jika masih mencuri lagi, maka ia akan dihukum pancung ${ }^{55}$.

If a thiefe be apprehended that hath Stolen any thinge to the value of 4 mace, vizt 05 s English, he is with all Speed carryed to the pallace, and before the chiefe Orongkay's face both his hands are cutt off in the joynts, for the Secound Small crime his feet, and, upon his committinge a third, his head. Yet, if the first crime be any thing considerable vizt. To the value of a cow or buffolo which exceedeth not 30 s English, it is present death... ${ }^{56}$

Dilihat dari bentuk hukuman masa Nakiyatuddin, maka hukuman potong tangan dan $\mathrm{kaki}^{\mathrm{5} 7}$ dapat dikatakan sesuai dengan hukum Islam, walaupun saya tidak tahu prosedur pengadilan dan dasar hukuman tersebut: benarkah berdasarkan hukum Islam atau hanya hukum adat yang berlaku saat itu. Tetapi hukuman mati sama sekali tidak sesuai dengan hukum Islam. Kemungkinan besar hukuman pencurian ini berdasarkan hukum adat atau hukum sultan.

Jika seseorang dihukum mati, maka ada cara khusus dalam pelaksanaan hukuman ini. Petugas pengadilan akan mengikat tangan terdakwa, kemudian dibawa ke tempat eksekusi. Mereka memotong bambu menjadi dua berukuran panjang masing-masing 1 meter: 1 bambu diletakkan di bawah leher terdakwa dan 1 bambu lagi ditaruh di

\footnotetext{
${ }^{53}$ Ibid, hal. 315.

${ }^{54} \mathrm{Ibid}$., hal. 316.

${ }^{55}$ Ibid., hal. 315.

${ }^{56}$ Ibid.

${ }^{57}$ Ibid., hal. 313-4.
} 
belakang tengkuk. Setelah itu, mereka memberi makan terdakwa dan mempersilahkannya berwudhu. Lalu, seorang ulama membimbing pengucapan 2 kalimat syahadat. Setelah itu, seorang algojo mencekik leher terdakwa dan algojo yang lain menusuk jantungnya. Ketika terdakwa telah mati, mereka menyulaknya dengan satu batang bambu berukuran kira-kira $20-40 \mathrm{~cm}$. panjang agar jenazah terdakwa dapat berdiri seperti layaknya suatu penyaliban. Kemudian, jenazah terdakwa yang telah disulak itu dibawa ke suatu tempat umum dan dipertontonkan selama beberapa hari. Keluarga terdakwa atau temantemannya dapat mengambilnya dan menguburkannya, atau jika ia tidak mempunyai keluarga maka sang algojo yang akan menguburkannya $\mathrm{a}^{58}$.

Ketika Nakiyatuddin mangkat, Inayat Syah Zakiyatuddin (16781688) menggantikannya. Praktek hukuman pada masa Zakiyatuddin dilaporkan oleh William Dampier, seorang Inggris yang datang ke Aceh pada 20 Mei 1688, akhir kekuasaan sang Ratu. Hukuman pencurian pada masa Zakiyatuddin ada dua: pencurian kecil dan besar seperti dilaporkan Dampier. Menurutnya, jika seorang mencuri tanpa kekerasan dan untuk pertama kalinya, ia hanya dihukum dengan hukuman cambuk ${ }^{59}$. Karena pencurian ini dianggap pencurian kecil. Tegasnya pencurian terhadap barang-barang yang kurang besar nilainya. Sebaliknya, jika ia mencuri dengan kekerasan, dan tentu nilai curiannya besar juga dikategorikan sebagai jenis pencurian besar. Untuk hukumannya, Dampier menulis:

Si on attrape un voleur, pour la première fois qu'il tombe en faute, on lui coupe la main droite depuis le poignet; pour la seconde, on lui coupe l'autre poignet; quelquefois au lieu d'une main, on lui coupe un pied ou tous les deux ensemble; et d'autres fois, mais rarement les deux mains et les deux pieds. ${ }^{60}$

Dari kesaksian Dampier tersebut kita mengetahui bahwa hukuman untuk pertama kali bagi pencuri adalah dipotong tangan kanannya.

${ }^{58}$ Bowrey, Op. Cit., hal. 316-317. Ketika berada di Aceh, Bowrey menyaksikan orang yang dijatuhi hukuman mati dengan cara seperti ini.

59 William Dampier, Supplement du Voyage autour du monde, contenant une description d'Achin.... du royaume de Tonquin...et de la baye de Campêche....Vol. III, Amsterdam: Paul Marret, 1701, hal. 153.

${ }^{60}$ Dampier, Op. Cit., hal. 152. 
Jika ia mencuri lagi, maka tangan kirinya yang dipotong, atau dipotong kakinya atau kadang-kadang tangan dan kakinya sekaligus, atau, tapi sangat jarang terjadi, kedua tangan dan kakinya ${ }^{61}$. Jika tangan dan kakinya sudah buntung, tapi masih mencuri, maka dibuang ke Pulau Way untuk diasingkan seumur hidupnya ${ }^{62}$. Dari kesaksian Dampier ini dapat dinilai bahwa hukuman pencurian pada masa Zakiyatuddin mungkin telah sesuai dengan hukum syariah. Demikian juga hukuman pengasingan ke pulau dapat dijumpai jenis hukuman tersebut dalam hukum Islam yaitu taghrîb (pengasingan). Namun demikian, kita tidak mengetahui sama sekali jika sultanah menghukumnya atas pertimbangan hukum Islam atau hanya menerapkan hukum yang telah berlaku, yaitu hukum adat. Adapun hukuman potong tangan dan kaki sekaligus tidak dijumpai dalam hukum Islam. Hukuman ini kemungkinan berdasarkan hukum adat atau hukum sultan.

Harus ditegaskan disini bahwa hukuman potong tangan dan kaki yang berlaku di Aceh bukan saja untuk pidana pencurian, tetapi berlaku juga bagi semua orang yang melakukan kesalahan apa saja dan sekecil apapun oleh rakyat biasa ataupun oleh pegawai kerajaan. Kepala Daerah (Panglima) Tiku dipotong tangan dan kakinya oleh Iskandar Muda karena tidak memberikan $15 \%$ bagi hasil penjualan lada dan emas $^{63}$. Bahkan menurut Beaulieu, Sultan Iskandar Muda setiap hari kerjaannya menghukum orang dengan memotong tangan, kaki. Hidung, kuping, mencongkel mata dstnya ${ }^{64}$. Dengan demikian, sulit untuk menyimpulkan bahwa hukuman pencurian didasarkan atas hukum Islam. Saya cenderung mengatakan bahwa hukum pidana pencurian yang digunakan di Aceh adalah hukum adat dan bukan hukum Islam.

${ }^{61}$ Dampier, Op. Cit., hal. 152.

${ }^{62} \mathrm{Ibid}$.

${ }^{63}$ F.C. Danvers dan K. Foster (ed.), "Letter Received by the East India Company from its Servant in the East”, London: 1896-1902, vol. V,h. 170, dan vol. VI, h. 68, dikutip dari J. Kathirithamby-wells, "Achehnese control Over West Sumatra up to the Treaty of Painan, 1663", Journal of South East Asian History X, no. 3 (1696): hal. 453-479, hal. 461.

${ }^{64}$ Beaulieu, Op. Cit., hal. 202. 


\section{Minuman Keras}

Sultan Alaudin Perak (1579-1586), sultan ke-8, tercatat sebagai sultan yang pertama kali melarang minuman yang memabukkan di kesultanan Aceh. Sumber lokal, Bustanu 's-Salatin, menyatakan bahwa Sultan Alaudin Perak adalah sultan yang baik dan adil. Ia menerapkan syariat Muhammad, yaitu melarang kepada rakyat Aceh meminum minuman yang memabukkan dan adu ayam ${ }^{65}$. Sayangnya, kita tidak tahu lebih jauh hukuman apa yang diterapkan bagi peminum khamr, karena tidak ada sumber yang menginformasikannya. Peraturan yang diterapkan masa Alauddin itu hilang seiring dengan wafatnya.

Pada masa sultan berikutnya, Alauddin Riayat Syah Sayyid alMukammil (1588-1614), sultan ke-10, larangan minum yang memabukkan dan adu ayam tidak berlaku lagi. James Lancaster, orang Inggris yang berdagang di Aceh pada 1602, mengatakan bahwa Sultan menyuguhkan arak kepada Jenderal Inggris dan dirinya pada saat penyambutan rombongannya. Sultan al-Mukammil sendiri minum arak bersama mereka yang menurut Lancester merupakan adat kebiasaan kerajaan $^{66}$.

Berdasarkan kesaksian Francois Martin de Vitre, orang Prancis yang berada di Aceh pada 24 Juli-20 November 1602, menyatakan bahwa orang-orang Aceh banyak minum arak, karenanya mereka sering mabuk. Ia menulis:

...Ils distillent une liqueur qu'ils appellent arack, forte comme de l'eau-de-vie, composée avec des cannes à sucre, du riz, des noix d'inde, dont ils s'enivrent souvent. ${ }^{67}$

Pada 26 Juli 1602, Francois melihat banyak orang yang berjualan minuman yang memabukkan di tepi jalan-jalan di kota Aceh ${ }^{68}$. Esok lusanya, 28 Juli 1602, Francois dan teman-temannya pergi ke

\footnotetext{
${ }^{65}$ Nuruddin a-Raniri, "Bustanu 's-Salatin, Bab II, Fasal 13", ed. T. Iskandar, Kuala Lumpur: Dewan Bahasa dan Pustaka, 1966, hal. 33.

${ }^{66}$ James Lancester, "The Voyage Made to East India by Master James Lancester", dalam "Purchas His Pilgrimes", ed. Samuel Purchas, book III, hal 154-160, London: William Stansby, 1625, hal. 154.

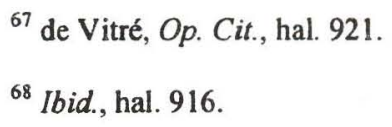


Kesultanan Pedir dimana Sultan Husain ${ }^{69}$, anak al-Mukammil, menjadi rajanya. Pada pesta penyambutan, Sultan Husain menyuguhkan arak kepada mereka dalam jumlah banyak ${ }^{70}$.

Kebiasaan minum Khamr orang Aceh diperkuat oleh kesaksian Wybrandt van Waarwyk, laksamana Belanda, yang mengungkapkan bahwa orang-orang Aceh suka minum minuman yang memabukkan (arak) sampai mabuk ${ }^{71}$. Dari beberapa sumber Eropa ini, nampak bagi kita bahwa minuman arak adalah tradisi masyarakat Aceh dan adat kebiasaan kerajaan, dan karenanya tidak ada hukuman bagi peminum khamr.

Setiap Sultan mempunyai hukum sendiri. Nampaknya itulah yang terjadi di Kesultanan Aceh. Larangan minuman yang memabukkan berlaku lagi pada masa Sultan Iskandar Muda (1607-1636), Sultan ke12. Bustanu 's-Salatin menyebutkan bahwa Iskandar Muda menerapkan syariat secara ketat. Ia memerintahkan rakyat Aceh shalat 5 waktu, puasa Ramadhan dan bahkan puasa sunah. Ia melarang mereka mengkonsumsi minuman yang memabukkan (arak) dan berjudi $^{72}$. Apa yang dilarang Iskandar Muda tentu sesuai dengan hukum Islam berdasarkan QS al-Maidah/5:90-91. Namun kita akan membandingkannya dengan kesaksian langsung seperti yang diungkapkan sumber Eropa apakah Iskandar Muda konsisten dengan peraturan yang ia buat sendiri.

Thomas Best, Orang Inggris yang datang ke Aceh pada 15 April 1613. Saat jamuan itu, Best disuguhi arak dalam jumlah yang sangat besar, bahkan menurut Best dapat memabukkan satu pasukan ${ }^{73}$. Kesaksian ini diperkuat oleh seorang pegawai Belanda yang bertugas di Aceh, dan dia berkata bahwa Sultan Iskandar Muda adalah seorang tiran yang suka mabuk-mabukan ${ }^{74}$. Dari kedua sumber Eropa ini, nampak bahwa ada kontradiksi yang sangat jelas antara peraturan yang

${ }^{69}$ Lombard, Op. Cit., hal. 7.

${ }^{70}$ de Vitré, Op. Cit., hal. 918.

${ }^{71}$ Van Waarwyk, Op. Cit., hal. 597.

${ }^{72}$ Ar-Raniri, Op. Cit., hal. 35-6.

${ }^{73}$ Thomas Best, "A Journall of The Teenth Voyage To The East-India", dalam "Purchas His Pilgrimes", ed Samuel Purchas, book IV, hal. 456-466, London: William Stansby, 1625, hal. 463.

${ }^{74}$ Dagh-Register 1631-1634, h. 239, dikutip dari Djajadiningrat, Op. Cit., hal. 54. 
dibuat oleh sultan, yaitu melarang konsumsi minuman memabukkan, dan perbuatannya. Hal ini menjelaskan kenapa tidak ada hukuman tegas bagi peminum khamar.

Kita baru mengetahui hukuman yang diberlakukan bagi pengkonsumsi arak pada masa Tajul Alam Safiyatuddin (1641-1675). Sultanah ke-14, putri Iskantar Muda dan istri Iskandar Thani. Jacob Compostel, seorang utusan Belanda di Aceh, melaporkan bahwa umat Islam di Aceh dilarang minum minuman yang memabukkan. Adapun non-muslim selalu mempunyai hak untuk minum khamar ${ }^{75}$. Memang menurut hukum Islam, non-muslim boleh membuat, menjual, mengirim, dan meminum khamar ${ }^{76}$. Dilihat dari satu sisi ini saja, nampak bahwa Safiyatuddin menerapkan hukum Islam, karena aturannya sesuai dengan hukum Islam. Namun apakah ia benar-benar menerapkannya atas dasar dan bersumber hukum Islam, atau hanya kebijakan politiknya saja? Kita tidak mengetahuinya.

Yang pasti, hukuman bagi peminum khamr tidak sesuai dengan yang digariskan oleh hukum Islam. P. Soury, seorang utusan Belanda pada tahun 1642, melaporkan bahwa dua orang Eropa dipotong tangannya karena mengkonsumsi minuman yang memabukkan di kota Aceh $^{77}$. Jacob Compostel melaporkan bahwa 2 orang Aceh, yang tertangkap basah sedang mengkonsumsi minuman beralkohol di rumah seorang nakhoda asing bernama Fijgie, dihukum menelan timah panas $^{78}$. Dari kesaksian sumber-sumber Eropa ini dan membaca jenis hukuman bagi peminum khamr, maka jelas sekali bahwa hukuman tersebut sama sekali tidak berdasarkan hukum Islam, tetapi berdasarkan hukum adat atau hukum sultan, yaitu hukum sekehendak hati penguasa.

${ }^{75}$ K.A., 1031, "Daghregister of Compostel," f. 1207 , dikutip dari Amirul Hadi, "Islam and State in Sumatra A Atudy of Seven teenth-Century Aceh", Leiden. Boston: Brill, 2004, hal. 173.

${ }^{76}$ Al-Jazînî, Op. Cit., vol V, hal. 25,15.

${ }^{77}$ K.A., 1051, "Daghregister of P. Soury," ff. 562v.-563r., dikutip dari Hadi, Op. Cit., hal. 173.

${ }^{78}$ K.A., 1031, "Daghregister of Compostel," ff. dikutip dari Hadi, Op. Cit., hal. 174. 


\section{Pembunuhan}

Hukuman pembunuhan pertama kali yang dapat diketahui adalah pada masa Sultan Alauddin Riayat Syah Sayyid al-Mukammil (15881604), sultan ke-10, berdasarkan kesaksian Francois Martin de Vitre, orang Prancis yang berada di Aceh pada 24 Juli-20 November 1602. Ia menulis hukuman bagi pembunuhan:

Si quelqu'un tue, il faut qu'il meure de pareille façon ou est baillé aux éléphants, lesquels au commandement qu'on leur fait, avec une simple parole, les prennent avec leur trompe, les mettent sur leurs dents et les jettent en l'air ; retombant à terre, ils les pressent de leur pied. Ils sont baillés aux tigres qui sont plus cruels et farouches. ${ }^{79}$

Berdasarkan kesaksian Francois tersebut bahwa ada tiga jenis hukuman pembunuhan yang berlaku di Aceh, yaitu: pertama, pembunuh dihukum mati dengan cara yang sama ketika ia membunuh, kedua, pembunuh dihukum mati dengan cara diinjak-injak gajah setelah terlebih dulu dilempar ke udara dengan belalai mereka, dan ketiga, pembunuh dilempar ke tengah harimau yang sangat ganas, dan tentu menjadi santapan mereka. Jika ditelaah bentuk hukuman pembunuhan ini, maka dapat dipastikan hukuman pembunuhan ini berdasarkan hukum adat yang berlaku.

Pada masa berikutnya, sangsi pembunuhan diatur dengan cukup baik dalam Undang-Undang Aceh, atau dikenal dengan UndangUndang Meukuta Alam, yang dibuat pada masa Sultan Iskandar Muda (1607-1636), sultan ke-12. Pasal-pasal yang mengatur pidana pembunuhan ialah pasal 25, 26, 32, 27 dan 38 .

Pasal 25 membicarakan sangsi hukuman pembunuhan disengaja yaitu dengan membayar diyyat ${ }^{80}$. Sebagian dari hukum ini sesuai dengan hukum Islam. Namun diyyat baru bisa dilaksanakan jika keluarga korban memaafkan dan mau menerima uang tebusan darah itu. Adapun pasal 26 membicarakan jumlah diyyat yang harus dibayar oleh si pelaku yaitu 100 ekor unta ${ }^{81}$. Hal ini sesuai dengan hukum Islam yang mengharuskan si pembunuh membayar diyyat sejumlah

${ }^{79}$ de Vitré, Op. Cit., hal. 922.

${ }^{80}$ Langen, Op. Cit., hal. 440, Jalil, Op. Cit., hal. 20, manuscrip, loc.cit.

${ }^{81}$ Langen, Loc. Cit., Jalil, Op. Cit., hal. 21, manuscrip, loc.cit. 
Kesultanan Pedir dimana Sultan Husain ${ }^{69}$, anak al-Mukammil, menjadi rajanya. Pada pesta penyambutan, Sultan Husain menyuguhkan arak kepada mereka dalam jumlah banyak ${ }^{70}$.

Kebiasaan minum Khamr orang Aceh diperkuat oleh kesaksian Wybrandt van Waarwyk, laksamana Belanda, yang mengungkapkan bahwa orang-orang Aceh suka minum minuman yang memabukkan (arak) sampai mabuk ${ }^{71}$. Dari beberapa sumber Eropa ini, nampak bagi kita bahwa minuman arak adalah tradisi masyarakat Aceh dan adat kebiasaan kerajaan, dan karenanya tidak ada hukuman bagi peminum khamr.

Setiap Sultan mempunyai hukum sendiri. Nampaknya itulah yang terjadi di Kesultanan Aceh. Larangan minuman yang memabukkan berlaku lagi pada masa Sultan Iskandar Muda (1607-1636), Sultan ke12. Bustanu 's-Salatin menyebutkan bahwa Iskandar Muda menerapkan syariat secara ketat. Ia memerintahkan rakyat Aceh shalat 5 waktu, puasa Ramadhan dan bahkan puasa sunah. Ia melarang mereka mengkonsumsi minuman yang memabukkan (arak) dan berjudi $^{72}$. Apa yang dilarang Iskandar Muda tentu sesuai dengan hukum Islam berdasarkan QS al-Maidah/5:90-91. Namun kita akan membandingkannya dengan kesaksian langsung seperti yang diungkapkan sumber Eropa apakah Iskandar Muda konsisten dengan peraturan yang ia buat sendiri.

Thomas Best, Orang Inggris yang datang ke Aceh pada 15 April 1613. Saat jamuan itu, Best disuguhi arak dalam jumlah yang sangat besar, bahkan menurut Best dapat memabukkan satu pasukan ${ }^{73}$. Kesaksian ini diperkuat oleh seorang pegawai Belanda yang bertugas di Aceh, dan dia berkata bahwa Sultan Iskandar Muda adalah seorang tiran yang suka mabuk-mabukan ${ }^{74}$. Dari kedua sumber Eropa ini, nampak bahwa ada kontradiksi yang sangat jelas antara peraturan yang

${ }^{69}$ Lombard, Op. Cit., hal. 7.

${ }^{70}$ de Vitré, Op. Cit., hal. 918.

${ }^{71}$ Van Waarwyk, Op. Cit, hal. 597.

${ }^{72}$ Ar-Raniri, Op. Cit., hal. 35-6.

73 Thomas Best, "A Journall of The Teenth Voyage To The East-India", dalam "Purchas His Pilgrimes", ed Samuel Purchas, book IV, hal. 456-466, London: William Stansby, 1625, hal. 463 .

${ }^{74}$ Dagh-Register 1631-1634, h. 239, dikutip dari Djajadiningrat, Op. Cit., hal. 54. 
dibuat oleh sultan, yaitu melarang konsumsi minuman memabukkan, dan perbuatannya. Hal ini menjelaskan kenapa tidak ada hukuman tegas bagi peminum khamar.

Kita baru mengetahui hukuman yang diberlakukan bagi pengkonsumsi arak pada masa Tajul Alam Safiyatuddin (1641-1675). Sultanah ke-14, putri Iskantar Muda dan istri Iskandar Thani. Jacob Compostel, seorang utusan Belanda di Aceh, melaporkan bahwa umat Islam di Aceh dilarang minum minuman yang memabukkan. Adapun non-muslim selalu mempunyai hak untuk minum khamar ${ }^{75}$. Memang menurut hukum Islam, non-muslim boleh membuat, menjual, mengirim, dan meminum khamar ${ }^{76}$. Dilihat dari satu sisi ini saja, nampak bahwa Safiyatuddin menerapkan hukum Islam, karena aturannya sesuai dengan hukum Islam. Namun apakah ia benar-benar menerapkannya atas dasar dan bersumber hukum Islam, atau hanya kebijakan politiknya saja? Kita tidak mengetahuinya.

Yang pasti, hukuman bagi peminum khamr tidak sesuai dengan yang digariskan oleh hukum Islam. P. Soury, seorang utusan Belanda pada tahun 1642, melaporkan bahwa dua orang Eropa dipotong tangannya karena mengkonsumsi minuman yang memabukkan di kota Aceh $^{77}$. Jacob Compostel melaporkan bahwa 2 orang Aceh, yang tertangkap basah sedang mengkonsumsi minuman beralkohol di rumah seorang nakhoda asing bernama Fijgie, dihukum menelan timah panas $^{78}$. Dari kesaksian sumber-sumber Eropa ini dan membaca jenis hukuman bagi peminum khamr, maka jelas sekali bahwa hukuman tersebut sama sekali tidak berdasarkan hukum Islam, tetapi berdasarkan hukum adat atau hukum sultan, yaitu hukum sekehendak hati penguasa.

${ }^{75}$ K.A., 1031, "Daghregister of Compostel," f. 1207 , dikutip dari Amirul Hadi, "Islam and State in Sumatra A Atudy of Seven teenth-Century Aceh", Leiden. Boston: Brill, 2004, hal. 173.

${ }^{76}$ Al-Jazîrî, Op. Cit., vol V, hal. 25,15.

${ }^{77}$ K.A., 1051, "Daghregister of P. Soury," ff. 562v.-563r., dikutip dari Hadi, Op. Cit., hal. 173.

${ }^{78}$ K.A., 1031, “Daghregister of Compostel," ff. dikutip dari Hadi, Op. Cit., hal. 174. 


\section{Pembunuhan}

Hukuman pembunuhan pertama kali yang dapat diketahui adalah pada masa Sultan Alauddin Riayat Syah Sayyid al-Mukammil (15881604), sultan ke-10, berdasarkan kesaksian Francois Martin de Vitre, orang Prancis yang berada di Aceh pada 24 Juli-20 November 1602. Ia menulis hukuman bagi pembunuhan:

Si quelqu'un tue, il faut qu'il meure de pareille façon ou est baillé aux éléphants, lesquels au commandement qu'on leur fait, avec une simple parole, les prennent avec leur trompe, les mettent sur leurs dents et les jettent en l'air ; retombant à terre, ils les pressent de leur pied. Ils sont baillés aux tigres qui sont plus cruels et farouches. ${ }^{79}$

Berdasarkan kesaksian Francois tersebut bahwa ada tiga jenis hukuman pembunuhan yang berlaku di Aceh, yaitu: pertama, pembunuh dihukum mati dengan cara yang sama ketika ia membunuh, kedua, pembunuh dihukum mati dengan cara diinjak-injak gajah setelah terlebih dulu dilempar ke udara dengan belalai mereka, dan ketiga, pembunuh dilempar ke tengah harimau yang sangat ganas, dan tentu menjadi santapan mereka. Jika ditelaah bentuk hukuman pembunuhan ini, maka dapat dipastikan hukuman pembunuhan ini berdasarkan hukum adat yang berlaku.

Pada masa berikutnya, sangsi pembunuhan diatur dengan cukup baik dalam Undang-Undang Aceh, atau dikenal dengan UndangUndang Meukuta Alam, yang dibuat pada masa Sultan Iskandar Muda (1607-1636), sultan ke-12. Pasal-pasal yang mengatur pidana pembunuhan ialah pasal 25, 26, 32, 27 dan 38 .

Pasal 25 membicarakan sangsi hukuman pembunuhan disengaja yaitu dengan membayar diyyat ${ }^{80}$. Sebagian dari hukum ini sesuai dengan hukum Islam. Namun diyyat baru bisa dilaksanakan jika keluarga korban memaafkan dan mau menerima uang tebusan darah itu. Adapun pasal 26 membicarakan jumlah diyyat yang harus dibayar oleh si pelaku yaitu 100 ekor unta ${ }^{81}$. Hal ini sesuai dengan hukum Islam yang mengharuskan si pembunuh membayar diyyat sejumlah

\footnotetext{
${ }^{79}$ de Vitré, Op. Cit., hal. 922.

${ }^{80}$ Langen, Op. Cit., hal. 440, Jalil, Op. Cit., hal. 20, manuscrip, loc.cit.

${ }^{81}$ Langen, Loc. Cit., Jalil, Op. Cit., hal. 21, manuscrip, loc.cit.
} 
100 ekor unta ${ }^{82}$. Sementara diyyat budak sesuai dengan tingkatan budak tersebut, demikian isi pasal $32^{83}$. Jika si pembunuh sudah

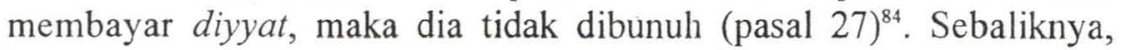
Kalau keluarga korban tidak mau menerima diyyat, maka si pembunuh harus dibunuh atau dikisas (pasal 28 ) $^{85}$. Setelah memperhatikan isi pasal-pasal pidana pembunuhan ini, maka dapat dikatakan bahwa isinya telah sesuai dan mengikuti apa yang digariskan oleh hukum Islam. Namun sayangnya, pertama, kita tidak tahu apakah pasal-pasal pembunuhan UU Aceh ini diterapkan atau tidak pada masa Iskandar Muda, karena kita tidak punya sumber yang menginformasikannya. Kedua, kita juga tidak tahu apakah pembuat UU Aceh ini mengerti dan mengambil sumbernya dari fikih. Yang saya lakukan di sinilah hanyalah analisa teks ditinjau dari fikih apakah ia sudah sesuai dengan apa yang digambarkan oleh hukum Islam atau belum, terlepas dari bagaimana mereka merancang UU Aceh tersebut.

Baru pada sultan berikutnya, kita mempunyai bukti bahwa sangsi pembunuhan UU Aceh itu dipraktikkan, yang juga sesuai dengan hukum Islam, yaitu pada masa Sultanah Tajul Alam Safiyatuddin (1641-1675), sultanah ke-14. Berdasarkan laporan Pieter Williemsz, seorang utusan Belanda di Aceh, bahwa ada seorang penduduk di Aceh dijatuhi hukuman mati karena telah membunuh orang oleh Kadi Malikul Adil ${ }^{86}$. Tetapi si terpidana itu meminta ke Kadi agar dirinya tidak dibunuh, dan sebagai gantinya ia membayar uang sejumlah 388 tahil (15 gram emas), satu jumlah yang besar saat itu. Kadi tidak berani memutuskan sendiri dan dia harus memutuskan berkonsultasi dengan suiltanah Safiyatuddin yang pada akhirnya permintaan itu dikabulkan oleh pengadilan ${ }^{87}$. Dari sini nampak bahwa hukuman

${ }^{82}$ Ibn Rusyd, Op. Cit., vol. II, hal. 307, Sâbiq, Op. Cit., vol. II hal. 466-7.

${ }^{83}$ Langen, loc.cit., Jalil, Op. Cit., hal. 22, manuscrit, loc.cit. Pasal ini sesuai dengan hukum Islam, menurut Hanafi diyyat seorang budak tidak boleh melebihi orang merdeka. Lihat Ibn Rusyd, Op. Cit., vol. II, hal. 310-11.

\footnotetext{
${ }^{84}$ Langen, Loc. Cit., Jalil, Op. Cit, hal. 21, Manuscrit, Loc. Cit.

${ }^{85}$ Langen, Loc. Cit., Jalil, Op. Cit., hal. 21, Manuscrit, Loc. Cit.

${ }^{86}$ Pejabat tinggi kesultanan Aceh yang menangani masalah hukum dan peradilan. Ia berfungsi sebagai ketua mahkamah syariah atau pengadilan agama di kesultanan Aceh. Kadi Malikul Adil pernah disebut oleh Bowrey dan ia pernah menulis dalam kesaksiannya dengan istilah Inggris Lord Chiefe Justice, Bowrey, Op. Cit., hal. 315.
} 
pembunuhan masa Safiyatuddin kemungkingan telah mengikuti hukum Islam. Hukuman pertama yaitu hukuman mati sesuai dengan syariah yaitu qisas. Oleh karena qisas tidak dilaksanakan, maka hukuman kedua berupa pembayaran sejumlah uang juga sesuai dengan hukum Islam yaitu diyyat (uang darah yang diterima si keluarga korban).

Namun demikian, hukum ini tidak selamanya diterapkan. Pada masa sultanah berikutnya, sultanah Syah Zakiyatuddin (1667-1688), sultanah ke16 hukuman kisas tidak berlaku, dan kembali kepada hukum adat. Jika seseorang berbuat tindakan kriminal dan dijatuhi hukuman mati, William Dampier, seorang Inggris, menulis:

On les empale quelquefois sur un pieu, qui entre par le fondement, passe à travers les boyaux et vint sortir par le cou. Ce pieu est de la grosseur de la cuisse d'un homme, planté ferme dans la terre et le bout pointu qui en parait au dehors est de douze ou quatorze pieds de haut. ${ }^{88}$

Bentuk lain dari hukuman mati itu, Dampier menulis:

Ils forment un grand cercle, au milieu duquel le criminel est placé, avec des armes auprès de lui, dont l'usage est permis en pareille rencontre, à savoir, une épée, une crosse et une lance. Lorsque le temps de se battre est venu, on le délie et on lui laisse la liberté de prendre ses armes. Les spectateurs tout prêts à le recevoir, chacun les armes à la main, ne remuent pas de leur place, jusqu'à ce que le criminel approche. Il pousse d'ordinaire un grand cri lors qu'il part, et il envisage fièrement la multitude, mais il est bientôt renversé par terre, à coups des lances qu'on lui darde et ensuite à coups d'épées et de crosses. ${ }^{89}$

Berdasarkan kesaksian Dampier ada 2 macam bentuk hukuman mati: pertama, disulak, yaitu hukuman dengan cara terpidana didirikan diatas sebuah bambu, sebesar paha orang yang ujungnya sangat runcing, lalu dia dinaikkan badannya dan ditusukkan ke anusnya hingga tembus ke leher dan keluar sampai ke mulut. Mayatnya

\footnotetext{
${ }^{87}$ K.A. 1051, Daghregister of Peter Willemsz, f. 250 v. dikutip dari Hadi, Op. Cit.,
} hal. 170 .

\footnotetext{
${ }^{88}$ Dampier, Op. Cit., hal. 154.

${ }^{89}$ Ibid.
} 
dipertontonkan di lapangan hingga beberapa hari. Dampier sendiri menyaksikan dengan mata kepala sendiri ada seorang yang dihukum dengan cara disulak, tapi sayangnya tidak diketahui penyebab ia dihukum demikan. Kedua, si terpidana diletakkan di tengah khayalak orang ramai, dan dia harus berhasil lari dari kerumunan itu dengan berbekal sebilah pedang. Biasanya semua terpidana mati terbunuh terpotong-potong oleh hunusan pedang lautan massa ${ }^{90}$. Dari keterangan Dampier ini nampak jelas bahwa hukuman mati yang diterapkan bagi pembunuh berdasarkan hukum adat yang berlaku saat itu atau hukum sultan.

\section{E. Murtad}

Fatwa mati pertama kali atas kasus murtad terjadi di Kesultanan Aceh pada paruh pertama abad ke-17, tepatnya tahun 1636. Fatwa ini dikeluarkan oleh Nuruddin Ar-Raniri, Syeikh al-Islam Kesultanan Aceh pada masa Iskandar Thani (1636-1641). Fatwa Ar-Raniri berkaitan dengan ajaran tasawuf wujudiyyah Ibn 'Arabi oleh Hamzah al-Fansuri ${ }^{91}$ dan Syamsuddin al-Sumatra' $i^{92}$. Dalam bukunya Hujjat alSiddiq Lidaf'i Ahli al-Zindiq, Ar-Raniri mengkritik secara keras ajaran al-Sumatra'i dan Fansuri, bahkan ia menghukumi kereka sebagai orang zindiq dan $\mathrm{kafir}^{93}$. Lebih mengerikan lagi, dalam karyanya Tibyan Fi Ma'rifat al-Adyan ${ }^{94}$, Ar-Raniri mengeluarkan fatwa mati bagi murid-murid Syamsuddin al-Sumatra'i karena mereka adalah

\section{${ }^{90}$ Ibid.}

${ }^{91}$ Untuk mengetahui lebih jauh mengenai tasawuf al-Fansuri, lihat Syed Muhammad Naguib al-Attas, "The Mysticism of Hamzah Fansuri", Kuala Lumpur: University Of Malaya Press, 1970.

${ }^{92}$ Untuk mengetahui lebih lanjut tasawauf al-Sumatra'i, lihat Abdul Azis Dahlan, "Tasawuf Syamsuddin Sumatrani," Disertasi Doktor, Tidak Diterbitkan, IAIN Syarif Hidayatullah Jakarta, 1992.

93 Nuruddin Ar-Raniri, "Hujjat al Shiddiq Lidaf'i Ahl al-Zindiq (1634-1644)", dalam Raniri and The Wujudnya Of $17^{\text {th }}$ Century Acheh, ed. Syed Muhammad Naguib alAttas, Singapore: MBRAS, 1966, hal. 80-142.

${ }^{94}$ Buku ini ditulis ar-Raniri atas permintaan para ulama dan rakyat Aceh untuk mengurangi bahkan menghapus konflik yang diakibatkan oleh ajaran wahdat al-wujud yang diajarkan oleh Hamzah al-Fansuri dan Syamsuddin al-Sumatra'i, lihat Alef Theria Wasim, "Hujjat al-Siddîk Li Dafi Ahl al-Zindîk: Suatu Telaah terhadap Karya Nûr al-Dîn al-Rânîrî," Tesis Master Tidak Diterbikan, IAIN Sunan Kalijaga, 1986, hal. 206. 
orang-orang zindiq (ateis), mulhid (kafir) dan kafir. Ar-Raniri juga memerintahkan untuk membakar semua karya Al-Sumatra'i. Ar-Raniri menulis:

... Maka taklala nyata kaum wujudiyah yang zindiq lagi mulhid dan sesat daripara murid Syamsuddin alSumatra'i... maka mereka berbahaslah bersama kami di hadapan Sultan yang paling shaleh pada masanya, semoga Allah menempatkannya dalam surganya yang dicintai, tuan kami Sultan Iskandar Thani Ala'uddin Mughayat Syah yang berjuluk Marhum Darus Salam yang menegakkan agama Allah... Dan berkatalah para murid Syamsuddin bahwa $<$ Allah adalah jiwa kami dan wujud kami, dan kami adalah jiwa-Nya dan wujud-Nya> ... maka aku karang, untuk membatalkan perkataan mereka yang batil dan aqidah mereka yang rusak, sebuah petikan untuk mencari perlindungan dari empunya bayang-bayang... aku berkata bahwa sesungguhnya kalian mempermainkan masalah ketuhanan, seperti Firaun yang mengaku <bahwa aku tuhan kalian yang paling tinggi>, padahal sesungguhnya mereka itu adalah kaum yang kafir, masamlah muka mereka dan tertunduklah kepala mereka, dan mereka adalah orang-orang yang musyrik... maka kaum muslim berfatwa atas kekafiran mereka dan agar membunuh mereka, ada diantara mereka yang bertaubat dan ada juga yang menolak, mereka yang bertaubat telah kemmbali ke akidah yang semula dari akidah yang batil... maka terbunuhlah para tentara kaum zalim...95.

Dengan fatwa Ar-Raniri tersebut, hampir semua karya alSumatra'i ludes terbakar hanya sedikit yang tersisa hingga hari ini dan banyak muridnya yang mati dibunuh. Inilah fatwa kedua hukuman mati dari seorang mufti, fakih, alim di Nusantara yang mengakibatkan tumpahnya darah orang-orang yang belum tentu salah. Alasan fatwa mati atas murid al-Sumatra'i karena mereka mengatakan InnalLâha nafsunâ wa wujûdunâ, wa nahnu nafsuhu wa wujûduhu

${ }^{95}$ Nuruddin ar-Raniri, "Tibyan Fi Ma'rifat al-Adyan (1636)", dalam "Twee Maleise Geschrifien Van Nuruddin ar-Raniri”, ed. P. voorhoeve, 128 hal, Leiden: E.J. Brill, 1995, hal. 3-5. Saya langsung membaca teksnya dan menerjemahkannya langsung dari bahasa Arab ke bahasa Melayu. Lihat juga versi Jawinya dalam pengantar Teuku Iskandar dalam Ar-Raniri (Iskandar), Bustanu... Op. Cit., hal. 8. 
(Sesungguhnya Allah adalah jiwa kami dan wujud kami, dan kami adalah jiwaNya dan wujudNya). Sementara tuduhan zindiq, mulhid, dan kafir atas al-Sumatra'i karena ia mengatakan bahwa dunia adalah abadi (qadîm) dan Alquran adalah ciptaan (makhlûq), dan dunia adalah emanasi dari Allah. Akibat dari fatwa ini, banyak kaum muslim yang dibantai, yaitu mereka yang teguh dengan keyakinan sufistiknya, karena cap sesat, zindiq, dan mulhid sama dengan murtad yang dalam hukum Islam yang hukumannya tidak lain adalah hukuman mati ${ }^{96}$.

Kasus ini mengingatkan saya pada apa yang pernah terjadi di Jawa, pada abad ke-16. Syeikh Siti Jenar (Syekh Lemah Abang), seorang sufi besar panteistik yang terpengaruh oleh ajaran Ibnu Arabi dihukum mati olah Wali Songo. Ia dihukum murtad, karena telah mengatakan:

Iya ingsun iki Allah, endi si malih, mapan orana malih, saking ingsun iki. (Aku adalah Allah, Aku tidak bisa menjadi orang lain, tidak ada yang abadi kecuali Aku).

Karena ucapan ini, ia dihukum mati. Para Wali Songo bermusyawarah pada 5 Ramadan, hari Jumat, di Girigajah di Gunung Kedaton, Gresik untuk memutuskan kasusnya.

Menurut sumber lain, yaitu Babad Cerbon, diskusi diadakan di sebuah Masjid di Cirebon, di pegunugan Ceramai. Yang hadir dalam rapat untuk mengeluarkan fatwa atas kasus Syeikh Siti Jenar adalah Pangeran Bonang, Pangeran Cirebon, Pangerang Kalijaga, Shekh Bentong, Maulana Maghribi, Pangeran Girigajah, dan Syekh Lemah Abang (Syekh Siti Jenar) sendiri. Dalam rapat ulama tersebut, Syeikh Siti Jenar tetap pada pendiriannya menyebarkan paham wahdatul wujud dan kembali mengucapkan kata-kata panteistik tadi. Oleh karena itu, Pangeran Cirebon (Sunan Gunung Jati) menjatuhkannya hukuman mati. Ia berkata «Sampun tuwan dawa malih, puniku ing benjang winuwuh ang leboni ukume» (Jangan diteruskan lagi, besok pagi kamu dihukum mati!). Siti Jenar pun mati ditebas pedang karena fatwa Majelis Ulama Jawa saat itu. Kuburan Siti Jenar terletak tidak

${ }^{96}$ Sâbiq, Op. Cit., jilid II, hal. 386, Ibn Rušd, Op. Cit., jilid II, hal. 343. al-Ǧazîrî, Op. Cit., jilid V, hal. 422-423, lihat juga Bernard Lewis, "Some Observations on the Significance of Heresy in the History of Islam", "Studia Islamica I (1953)": hal. 43-63, hal. 5460, Hervé Bleuchot, Droit Musulman, II vols, Vol. II, Aix-en-Provence: Presses Universitaires d'Aix Marseille, 2002, jilid II, hal. 701. 
jauh dari makam Sunan Gunung Jati yang menjatuhkan fatwa mati baginya $^{97}$.

Selain kasus wahdatul wujud, Ar-Raniri juga mengeluarkan fatwa terhadap karya sastera Hikayat Sri Rama dan Hikayat Inderaputera, hanya karena kedua karya roman (India) ini tidak menyebut nama Allah. Ar-Raniri mengeluarkan fatwa tidak boleh membacanya, dan harus membuangnya ke kakus ${ }^{98}$.

Hukuman mati juga pernah dijatuhkan oleh Sultan Iskandar Thani, tetapi bukan kasus murtad. Ia menghukum mati orang-orang Portugis yang tidak mau masuk Islam dan mendeportasi pedagang-pedagang Cina yang berusaha memasukkan babi ke Aceh ${ }^{99}$.

\section{F. Perampokan}

Kasus perampokan ini tercatat pada masa Sultanah Nurul Alam Nakiyatuddin (1675-1678 M.), sultanah ke-15. Thomas Bowrey, Laksamana Inggris yang bertugas di India dan berkunjung ke Aceh, menginformasikan bahwa setelah kematian Sultanah Safiyatuddin, penguasa ke-14, sekitar tahun 1675 , terjadi pemberontakan melawan ratu yang baru terpilih, Nakiyatuddin. Pemberontakan yang berjumlah 700 orang menyerang istana dan mencuri 7 pikul emas (sekitar 6.176 $\mathrm{kg}$ emas) dari kesultanan. Pasukan kesultanan menyerang mereka, hasilnya: 500 orang tertangkap dan 200 orang mati terbunuh. Syaikh al-Islam ${ }^{100}$, yang juga menjabat kepala hakim, menghukum mati semua pemberontak, kecuali seorang ulama yang dihukum potong kaki dan tangan, serta harta bendanya dirampas menjadi milik umum ${ }^{101}$. Jika

${ }^{97}$ G.W.J. Drewes, ed. "An Early Javanese Code of Muslim Ethics”, The Hague: M. Nijhoff, 1978, hal. 44-47. Apa yang terjadi di Nusantara ini mengingatkan saya kepada kasus Abû Mansûr al-Hallâj, sufi agung yang dihukum mati dengan cara digantung dicincang, dan dibakar di Baghdad pada tahun 922 M. Dua abad kemudian, Suhrawardi al-Maqtul mengalami hal yang sama. Ia dihukum mati di Aleppo, lihat Lewis, Op. Cit., hal. 61.

98 Richard Winstedt, "A History Of Classical Malay Litterature", Journal of The Malayan Branch Royal Asiatic Society XXXI, part 3 (1958): pp. 1-251, hal. 120.

${ }^{99}$ Anthony Reid, "Southeast Asia in the Age of Commerce 1450-1680", II vols, Vol. II, New Haven and London: Yale University Press, 1993, hal. 182.

${ }^{100}$ Kemungkinan besar Syeikh al-Islam ini adalah Abdurrauf al-Singkeli, yang memangku jabatan itu sejak tahun 1661 pada masa Safiyatuddin (1641-1675) hingga dia wafat tahun 1693.

${ }^{101}$ Bowrey, Op. Cit., hal. 313-314. 
dilihat dari keputusan Syaikh al-Islam ini, nampak bahwa hukuman pemberontakan itu telah sesuai dengan hukum Islam, yaitu 499 dihukum mati dan satu dipotong tangan dan kakinya, berdasarkan QS. Al-Ma'idah/5:33. Hukuman ini juga sesuai dengan UU Aceh pasal 41 mengenai pemberontakan ${ }^{102}$.

\section{Kesimpulan dan Penutup}

Secara umum hukum yang dipraktikkan di Aceh adalah hukum adat. Untuk hukum pidana yang digunakan adalah juga hukum adat, namun ada pula nuansa hukum Islamnya. Kita sudah melihat di atas bahwa para sultan Aceh ada yang menerapkan hukuman pelaku kriminal sesuai dengan tuntutan syariah seperti pencurian yang mengharuskan potong tangan dan kaki, tetapi seringnya hukuman ini melewati batasan yang telah ditetapkan oleh hukum Islam bahkan tidak ada hubungan dengannya. Atau satu contoh lagi, yaitu hukuman rajam bagi pezina yang telah menikah. Pada masa Alauddin alKahhar, hukuman rajam diterapkan dan dilaksanakan, tetapi pada masa Alauddin al-Mukammil, Iskandar Muda, Iskandar Thani, Safiyatuddin, Nakiyatuddin dan Zakiyatuddin, mereka menghukumnya dengan cara lain. Penerapan hukum Islam yang sebenarnya sangat sedikit. Yang ada adalah penerapan hukum adat dan yang lebih banyak lagi adalah penerapan apa yang saya sebut 'hukum sultan". Hal ini jauh dari bayangan kita yang selalu menduga bahwa kesultanan Aceh, sebagai pemerintahan Islam, mesti menerapkan hukum Islam. Ternyata, hal itu sama sekali jauh dari fakta sejarah yang ada. Para Sultan menghukum para pelaku tindak pidana sesuai dengan keinginan dan suasana hati mereka. Tidak ada aturan yang jelas untuk menjatuhkan hukuman tertentu karena tindak kriminal tertentu pula. Mereka menghukum para terdakwa tanpa melihat strata sosial: bangsawan atau orang biasa, kaya atau miskin.

Dapat disimpulkan bahwa kesultanan Aceh pada abad ke-16 dan ke-17 menggunakan dan menerapkan hukum adat, namun yang lebih sering diterapkan adalah apa yang saya sebut hukum sultan. Sebagai contoh, kesultanan Aceh membuat UU yang terdiri dari 105 pasal meliputi hukum adat, hukum Islam, dan hukum campuran antara keduanya. Hukum adat terdiri dari 89 pasal $(93,45 \%)$, hukum Islam 15 pasal $(15,75 \%)$ dan hukum campuran antara keduanya 1 pasal $(1,05 \%)$. Dari sini nampak dominasi hukum adat yang begitu kuat. Ditambah, praktik hukuman yang ada di Aceh, 
sebagaimana dipaparkan di atas, jelas memperkuat tesis saya bahwa hukum adatlah yang berlaku di Aceh, dan bukan hukum Islam.

Pencuri, pemberontak, pezinah, peminum khamar, murtad, perampok, pembunuh dan semua jenis tindak pidana lainnya dihukum dengan segera dan cepat: potong tangan, potong kaki, potong hidung, potong kuping, potong bibir, potong kemaluan, mata dicongkel, jari-jari tangan dimasukkan besi panas, tubuh digergaji, tubuh dipotong-potong, leher disembelih, dicekik, kepala dipancung, tubuh diinjak-injak dan ditarik oleh gajah, dilemparkan ke kawanan harimau, dibakar hidup-hidup, digantung, dimasukkan timah panas ke mulut, kemaluan ditusuk bambu, badan disulak dengan memasukkan bambu dari anus keluar hingga mulut, disalib, dan kemudian mayat dipajang berhari-hari untuk dipertontonkan ke publik. Semua ini menunjukkan bahwa kekuasaan adalah sumber hukum dan raja adalah penegak hukum yang tak pernah salah. Mereka tidak peduli dengan keberadaan UU yang ada. Mereka tidak peduli dengan batasan-batasan yang digarisbawahi oleh hukum Islam. Menghukum orang dengan kejam adalah jalan untuk menunjukkan kepada rakyat bahwa raja adalah penguasa tunggal. Dan hukuman yang sadis adalah cara untuk melanggengkan kekuasaan.

Ternyata hukuman sadis yang ada di Aceh bukanlah monopoli tunggal. Praktik hukuman kejam tersebut berlaku di hampir semua kebudayaan dan peradaban, termasuk dalam sejarah politik umat Islam, seperti di Mesir dan Turki.

Di Mesir, pada masa Mamalik (1250-1517), mereka menerapkan hal yang sama. Pembunuh, pencuri, perampok, penyamun, pezinah, pedofil, murtad, dan pemalsu uang, semua orang ini dibawa di hadapan sultan yang langsung menjatuhkan hukuman: hukuman mati, potong tangan, potong kaki, potong lengan, leher dicekik hingga matanya jatuh ke lantai, jari-jari dimasukkan cincin panas, pentil tetek dijepit dan ditarik dengan besi panas lalu mereka disuruh memakannya, digantung, badan digergaji menjadi dua, kepala dipenggal, kemaluan dipotong, disalib, disulak dengan cara memasukkan bambu dari anus hingga tembus ke mulut, lalu dipajang mayatnya di depan publik, dan terakhir mayatnya dibuang ke api ${ }^{103}$.

Khilafah Turki-Usmaniyyah juga mempraktikkan hukuman yang sama sepanjang abad ke-15 hingga abad ke-19. Para terdakwa dihukum potong tangan, kaki, hidung, kuping, dan kemaluan ${ }^{104}$, ketika dihukum mati: mereka

${ }^{103}$ M. Espéronnier, "La mort violente à l'époque Mamlouk: le crime et le châtiment", Der Islam 74, no. 1 (1997): hal. 137-155. Maryta Espéronnier, "Un regard du côté Mamlouk à travers les témoignages de Maqrîzi et d'Ibn Iyâs," dalam Les Ottomans et la Mort. Permanences et Mutations, ed. Gilles Veinstein, Leiden.New York.Köln: E.J. Brill, 1996, hal. 175-186. 
disulak, dicekik, dicincang, dipancung, lalu mayatnya dipertontonkan di depan umum beberapa hari dan kemudian mayatnya dilempar ke laut ${ }^{105}$.

${ }^{104}$ Uriel Heyd, "Studies in Old Ottoman Criminal Law", édité par V.L. Ménage. London: Oxford University Press, 1973, hal. 15. Mereka juga menghukum para pelaku kriminal dengan memotong jenggot, jidatnya ditandai, dan bayar denda untuk kasus pembunuha, perzinaan, luka dll, lebih lanjut lihat hal. 41-289.

${ }^{105}$ Matei Cazacu, "La mort infâme. Décapitation et exposition des têtes à Istanbul (XVe-XIXe siècles)", dalam "Les Ottomans et la Mort. Permanences et Mutations", ed. Gilles Veinstein, Leiden.New York.Köln: E.J. Brill, 1996, hal. 245-289. 


\section{Daftar Pustaka}

Al-'Awwa, Muhammad Salim. Fi Usûl al-Nizâm al-Islâm, Kairo: Dar alMa'arif, 1979.

al-Attas, Syed Muhammad Naguib. The Mysticism of Hamzah Fansuri, Kuala Lumpur: University Of Malaya Press, 1970.

al-Bukhari, Abu 'Abd Allah Muhammad Ibn Isma'il. Sahih al-Bukharil, ed Mustafa Dib al-Buga. VI vols. Vol. VI. Beirut:Mu'assasat al-Khidmat al-Tibâ'iyyat, 1980-1982, vol. VI.

al-Jazîrî, Abd Rahmân. Kitab al-Figh 'ala Madzâhib al Arba'ah, V vol., Beirut: Dar al-Fikr 1987 M./1406 H.

ar-Raniri, Nuruddin. Bustanu 's-Salatin, Bab II, Fasal 13, ed. T. Iskandar, Kuala Lumpur: Dewan Bahasa dan Pustaka, 1966.

. Tibyan Fi Ma'rifat al-Adyan (1636), dalam Twee Maleise Geschrifien Van Nuruddin ar-Raniri, ed. P. voorhoeve, $128 \mathrm{hlm}$, Leiden: E.J. Brill, 1995.

. Hujjat al Shiddiq Lidaf'i Ahl al-Zindiq (1634-1644), dalam Raniri and The Wujudnya of $17^{\text {th }}$ Century Acheh, ed. Syed Muhammad Naguib al-Attas, Singapore: MBRAS, 1966: 80-142.

al-Šâfi'i, Muhammad Ibn Idrîs. al-Umm, ed. Muhammad Zuhrî al-Nağğâr, VII vols, Beirut: Dâr al-Ma'rifa, t.t., vol. VI.

al-Tanûhî, Sahnûn Ibn Sa'ad. al-Mudawwana al-Kubrâ Li al-Imâm Mâlik, ed. 'Ali Ibn 'Abd Rahmân al-Hâšimi, XI vols, Kairo: Dâr al-Nashr, t.t., vol. XI.

Alam Muzaffar, \& Sanjay Subrahnyaman, Southeast Asia as Seen Froum Mughal India, Archipel 70, Paris, 209-237: 225-226.

Alfian, T. Ibrahim. Mata Uang Emas Kerajaan-Kerajaan di Aceh, Aceh: Museum Aceh, 1979.

Beaulieu, Augustin de. Memoires d'un voyage aux indes orientales 16191622, ed. Denys Lombard, Paris: Maisonnueve \& Larose,1996, hlm. 200. Bandingkan dengan cetakan pertama dari catatan Augustin de Beaulieu pada "Memoires du voyage aux indes orientales du general Bealieu Dresse par Luy-meme," dalam Relations de Divers Voyage Curieux Qui N'Ont Pas Este Publiees, ed. M. Thevenot, hlm 1-128, Paris: Sebastien Cramosy, 1664-1666. 
Best, Thomas. A Journall of The Teenth Voyage To The East-India,' dalam Purchas His Pilgrimes, ed Samuel Purchas, book IV, London: William Stansby, 1625: 456-466.

Bleuchot, Hervé. Droit Musulman, II vols, Aix-en-Provence: Presses Universitaires d'Aix Marseille, 2002, vol. II.

Bowrey, Thomas. A Geographical Account of Countries Round The Bay of Bengal 1669 to 1679, ed. R. C. Temple, 1993 ed., Cambridge: Hakluyt Society, 1905.

Braddel, Thomas. Silsilah Aceh from the Annals of Acheen, The Journal of the Indian Archipelago and Eastern Asia IV (1850): 598-606.

Cabaton, Antoine. Une histoire critique du sultanat d'Acheh écrite par un javanais, Revue du monde musulman: Paris, tanpa tahun dan edisi.

Cazacu, Matei. La mort infâme. Décapitation et exposition des têtes à Istanbul (XVe-XIXe siècles), dalam Les Ottomans et la Mort. Permanences et Mutations, ed. Gilles Veinstein, Leiden.New York.Köln: E.J. Brill, 1996: 245-289.

Dahlan, Abdul Azis. Tasawuf Syamsuddin Sumatrani, Disertasi Doktor, Tidak Diterbitkan, IAIN Syarif Hidayatullah Jakarta, 1992.

Dampier, William. Supplement du Voyage autour du monde, contenant une description d'Achin. du royaume de Tonquin.et de la baye de Campêche, Vol. III, Amsterdam: Paul Marret, 1701.

Danvers F.C., dan K. Foster (ed.), Letter Received by the East India Company from its Servant in the East, London: 1896-1902, vol. V,h. 170, dan vol. VI, h. 68, dikutip dari J. Kathirithamby-wells, Achehnese control Over West Sumatra up to the Treaty of Painan, 1663, Journal of South East Asian History X, no. 3 (1696): 453-479.

Davis, John. A Brief Relation of Master John Davis, dalam Purchas His Pilgrimes, ed. Samuel Purchas, book III, hlm. 116-124, London: William Stansby, 1625, vol. I.

de Vitré, François. Martin Description du premier voyage fait à Sumatra par les Français en l'an 1603 contenant les moeurs, lois, façons de vivre, religions \& habitudes des Indiens, dans Voyage de Pyrard de Laval aux Indes Orientales (1601-1611), ed. Xavier de Casto, Paris: 1603, cetak ulang Chandeigne 1998: 907-932.

Den Broeck, Pierre Van. Voyages de Pierre Van Den Broeck au Cap Vert, à Angola et aux Indes Orientales, dalam Recueil de voyages qui ont 
servi à l'établissement et aux progrès dela Compagnie des Indes Orientales, formée dans les Provinces-Unies des Pays-Bas, disunting oleh Constantin de Renneville, V jilid, jilid IV (mikrofilm, Amsterdam: E. Roger, 1705): 306-473.

Djajadiningrat, Hoesein. Kesultanan Aceh (Suatu Pembahasan Atas Bahanbahan Yang Tertera Dalam Karya Melayu Tentang Sejarah Kesultanan Aceh), terj. Teuku Hamid, Aceh: Proyek Rehabilitasi dan Perluasan Museum, 1979.

Dorleans, Bernard. Les Francais et L'Indonesie, Paris: Kailash, 2001.

Drewes, G.W.J., ed. An Early Javanese Code of Muslim Ethics, The Hague: M. Nijhoff, 1978.

Dulaurier, Ed. Chronique du royaume d'Atcheh, Journal Asiatique 3, no. VIII (1839): 47-81.

Espéronnier, M. La mort violente à l'époque Mamlouk: le crime et le châtiment, Der Islam 74, no. 1 (1997): hlm. 137-155. Maryta Espéronnier, Un regard du côté Mamlouk à travers les témoignages de Maqrîzi et d'Ibn Iyâs, dalam Les Ottomans et la Mort. Permanences et Mutations, ed. Gilles Veinstein, Leiden.New York.Köln: E.J. Brill, 1996: 175-186.

Gupta, Arun Kumar Das. Acheh in Indonesian Trade and Politics 1600-1641, Disertasi Doktor, Tidak Diterbitkan, Cornell University, 1962.

Hadi, Amirul. Islam and State in Sumatra A Atudy of Seven teenth-Century Aceh, Leiden. Boston: Brill, 2004.

Heyd, Uriel. Studies in Old Ottoman Criminal Law, édité par V.L. Ménage. London: Oxford University Press, 1973.

Iskandar, Teuku (éd.), De Hikajat Atjéh, Gravenhage: NV. De Nederlandsche Boek, 1959.

Jalil, Tuanku Abdul. Adat Meukuta Alam, Banda Aceh: Pusat Dokumentasi dan Informasi Aceh, 1991.

Juynboll, Th. W., dan P. Voorhoeve, Atjèh, dalam Encyclopédie de l'Islam, hlm. 761-766. Leiden dan Paris: E.J. Brill dan G.P.Maisonneuve \& Larose S.A., 1991.

Lancester, James. The Voyage Made to East India by Master James Lancester, dalam Purchas His Pilgrimes, ed. Samuel Purchas, book III, hlm 154-160, London: William Stansby, 1625. 
Lewis, Bernard. Some Observations on the Significance of Heresy in the History of Islam, Studia Islamica I (1953): 43-63.

Lombard, Denys. Martin de Vitré Premier Breton à Aceh (1601-1603)" Archipel 54 (1997): 3-12.

Marsden, William M. History de Sumatra, pent. M. Parraud. II vols. II. Paris: Chez Buisson, 1788.

. The History of Sumatra, Kuala Lumpur: Oxford Univesity Press, 1966 (1811).

Muslim, Abu al-Husayn. Sahih Muslim, ed. Muhammad Fu'ad 'Abd al-Bâqi. V vols. Vol. III. Kairo: Mustafa al-Babi al-Halabi, 1955.

Mundy, Peter. The Travel of Peter Mundy in Europe and Asia 1608-1667, ed R. C. Temple, V vols, Vol. III, Part:1, Travels in England, Western India, Achin, Macao \& The Canton River 1634-1637, London: The Hakluyt Society, 1919.

. The Travel of Peter Mundy in Europe and Asia 1608-1667, ed R. C. Temple, V vols., Vol. III, Part: II, Travel in Achin, Mauritius, Madagaskar and St. Helen 1638, London:The Hakluyt Society, 1919.

Qudâmah, Muwaffaq al-Dîn Ibn. al-Mugnî, XIII vols, Beirut: Dâr al-Kitâb al-'Arabiy, 1983/1403, vol. X, hlm. 120-121, Šamsuddîn al-Sarahsî, alMabsût, XXX vols, Beirut: Dâr al-Kutub al-'Ilmiyya, 1994/1414, vol. IX.

Reid, Anthony. Southeast Asia in the Age of Commerce 1450-1680, II vols, Vol. II, New Haven and London: Yale University Press, 1993.

Rushd, Abû al-Walîd Muhammad Ibn. Bidayat al-Mujtahid Wa Nihayat al Muqtasid, II vol., Beirut: Dar al-Fikr, t. t. vol. II.

Sabiq, Sayid. Fiqh Sunnah, III vol., Kairo:tanpa penerbit, 1988/1409, vol II.

Schmalkalden, Caspar. Die wundersamen reisen des Caspar Schmalkalden nach West- und Ostindien 1642-1652, édité par Wolfgang Joost, Weinheim: Acta Humaniora, 1983.

Undang-Undang Aceh, di Perpustakaan Nasional, kode M1. 533, 32, Jakarta, 1927.

Waarwyk, Wybrandt van. Voiage de quinza vaisseaux hollandois commandez par l'amiral Wybrandt van Waarwyk pour la com pagnie d'octroiindesorientales formee dans les provinces unies, dalam Recueil de voyages qui ont servi a l'etablissement et aux progress dela 
Compagnie des indes Orientales, forme dans les Provinces Unies des Pays-Bas, edited by Constantin de Renneville, V vol, h. 1-107, Amsterdam: E. Roger, 1702.

Wasim, Alef Theria. Hujjat al-Siddîk Li Daf'i Ahl al-Zindîk: Suatu Telaah terhadap Karya Nûr al-Dîn al-Rânîrî, Tesis Master Tidak Diterbikan, IAIN Sunan Kalijaga, 1986, hlm. 206.

Winstedt, Richard. "A History Of Classical Malay Litterature", Journal of The Malayan Branch Royal Asiatic Society XXXI, part 3 (1958): 1251.

Van Langen, K. F. H. De Inrichting Van Het Atjehsche Staatbestuur Onder Het Sultanaat, Bijdragen tot de Taal-Land-ben Volkkenkunde V, no. III (1888): hlm. 381-471.

Verhoeven, Pierre Willemsz. Voyage de l'amiral Pierre Willemsz Verhoeven aux indes orientales, di dalam Recueil de voyages qui ont servi à l'établissement et aux progrès de la Compagnie des Indes Orientales, formée dans les Provinces-Unies des Pays-Bas, disunting oleh Constantin de Renneville, V jilid, jilid IV, Amsterdam: E. Roger, 1705: 1-107.

\section{Media Televisi}

"Binalnya Polisi Syariah", dalam tayangan FAKTA edisi Selasa 1 Mei 2007 jam 23.00-23.25 WIB di ANTEVE. 